\title{
Review \\ Silver and Gold Nanoparticles for Antimicrobial Purposes against Multi-Drug Resistance Bacteria
}

\author{
Navid Rabiee ${ }^{1,2, *,+(D)}$, Sepideh Ahmadi ${ }^{3,4,+}$ (D) , Omid Akhavan ${ }^{1}$ (D) and Rafael Luque ${ }^{5, *(D)}$ \\ 1 Department of Physics, Sharif University of Technology, Tehran 11155-9161, Iran; oakhavan@sharif.edu \\ 2 School of Engineering, Macquarie University, Sydney, NSW 2109, Australia \\ 3 Student Research Committee, Department of Medical Biotechnology, School of Advanced Technologies in \\ Medicine, Shahid Beheshti University of Medical Sciences, Tehran 19857-17443, Iran; \\ speahmadi@yahoo.com \\ 4 Cellular and Molecular Biology Research Center, Shahid Beheshti University of Medical Sciences, \\ Tehran 19857-17443, Iran \\ 5 Departamento de Química Orgánica, Campus de Rabanales, Universidad de Córdoba, Edificio Marie \\ Curie (C-3), Ctra Nnal IV-A, Km 396, E14014 Cordoba, Spain \\ * Correspondence: navid.rabiee@mq.edu.au or nrabiee94@gmail.com (N.R.); rafael.luque@uco.es (R.L.) \\ + These authors contributed equally to this work.
}

check for updates

Citation: Rabiee, N.; Ahmadi, S.; Akhavan, O.; Luque, R. Silver and Gold Nanoparticles for Antimicrobial Purposes against Multi-Drug

Resistance Bacteria. Materials 2022, 15, 1799. https://doi.org/10.3390/ ma15051799

Academic Editor: Cristina Della Pina

Received: 13 December 2021

Accepted: 25 January 2022

Published: 27 February 2022

Publisher's Note: MDPI stays neutral with regard to jurisdictional claims in published maps and institutional affiliations.

Copyright: (C) 2022 by the authors. Licensee MDPI, Basel, Switzerland. This article is an open access article distributed under the terms and conditions of the Creative Commons Attribution (CC BY) license (https:// creativecommons.org/licenses/by/ $4.0 /)$.

\begin{abstract}
Several pieces of research have been done on transition metal nanoparticles and their nanocomplexes as research on their physical and chemical properties and their relationship to biological features are of great importance. Among all their biological properties, the antibacterial and antimicrobial are especially important due to their high use for human needs. In this article, we will discuss the different synthesis and modification methods of silver (Ag) and gold (Au) nanoparticles and their physicochemical properties. We will also review some state-of-art studies and find the best relationship between the nanoparticles' physicochemical properties and potential antimicrobial activity. The possible antimicrobial mechanism of these types of nanoparticles will be discussed in-depth as well.
\end{abstract}

Keywords: silver nanoparticles; gold nanoparticles; antimicrobial resistance; green chemistry

\section{Introduction}

Bacterial resistance is becoming a global challenge as microbes are continually changing. Every year, 33,000 people in Europe die from bacterial resistance, so new ways to fight bacteria are required [1,2]. The increase in nosocomial and acquired infections can be a significant problem due to multi-drug-resistant bacterial pathogens (MDRs) for which current antibiotic treatments are not effective [3,4]. Antibiotics are important in fighting bacterial infections, however, in recent years they have become increasingly resistant to treating infections. Excessive application of antibiotics causes microorganisms to undergo genetic changes over time to live antimicrobial use leading to antimicrobial resistance (AMR) [5]. Excessive usage of antibiotics and the progress of antibiotic resistance has become a global concern. The increase in nosocomial infections and viral infections, including influenza as well as SARS-CoV-2 in 2019, requires rapid risk assessment and immediate prevention and treatment. Recent research has warned of a link between SARS-CoV-2 and AMR [6-10].

AMR describes the resistance of any microbe to the drugs that are applied to kill them. Drug-resistant diseases cause about 0.7 million deaths a year, and if no attempt is made to control it, AMR deaths, at worst, could reach 10 million a year by 2050 [11-13]. As a result, it can be said that AMR is one of the most important threats to human health and causes an increase in mortality. AMR is a multipart apparatus whose etiology can be influenced by the individual, the bacterial strains, and the resistance mechanisms that are established.

The mechanism of AMR includes the restrictive uptake of a drug, inactivating a drug, altering a drug target, and active drug efflux [14,15]. Additionally, AMR has been reported 
at three increasing levels including extensive drug resistance (XDR), MDR, and pan-drug resistance (PDR) [16-19]. XDR was determined as non-susceptibility to, at minimum, one agent whenever two or fewer antimicrobial types were listed. PDR was determined as nonsusceptibility to all agents in all antimicrobial types. MDR was determined as attained nonsusceptibility to at least one agent in three or more antimicrobial types [20,21]. To overcome the problem of resistance, it will be essential to alter the protocols of applying antimicrobials so that these drugs are administered when all other treatment routes have failed.

Nanoparticles (NPs) can offer an alternative possible solution to battle MDR pathogens [22,23]. In fact, NPs with a size of less than $100 \mathrm{~nm}$ show a higher toxicity due to their exclusive possessions [24-28]. Several NPs, including silver (Ag) and gold (Au) NPs (and also copper (Cu) NPs [29-31], zinc (Zn) NPs [30,32,33], Nickel (Ni) NPs [34], platinum (Pt) NPs [35], and palladium (Pd) NPs [32,34]), have exposed different antimicrobial activities based on the physicochemical properties of each metal nanomaterial. Among these, Ag NPs showed more antimicrobial activities using multiple mechanisms. In addition to the synthesis method, the size and shape of Ag NPs show an important role in this activity. Interestingly, several reports show the high antimicrobial activity of Ag NPs with smaller sizes. These NPs can disrupt the bacterial cell membrane, affecting cell penetration and causing toxicity [36-39]. The antibiofilm activity of Ag NPs has been also shown in several studies. According to the properties of Ag NPs, they can improve the antibiofilm activity of conservative antimicrobials [40-42].

$\mathrm{Au}$ NPs are one of the significant branches of nanometal research, especially in antimicrobial activity [30,43]. Determinants of the antimicrobial effects of Au NPs are broadly studied, such as shape, size, concentration, and coating agent. Due to the electrical and optical properties of Au NPs, they have more consideration. One of the predominant properties is their localized surface plasmon resonance (LSPR), which shows a significant role in various applications such as biosensors. This occurs as the electrons on the surface of noble metal NPs interrelate with electromagnetic radiation, producing LSPR; it is because of this that metal NPs create strong extinction, useful in various scenarios [44]. Au NPs have been known to have unique properties to LSPR biosensors due to their spectral response to the location of the NP's surface [45].

The antibacterial activity of Au NPs can also be classified through the photothermal properties of Au NPs or their uses in photodynamic therapy (PDT) technology. Phothermal therapy (PTT) refers to transforming light into thermal energy by gold NPs. Gold nanorods (GNRs) and nanostars (GNSs) are used for this assay to eliminate bacteria. The PDT method is based on irradiating photosensitizers which produce reactive oxygen species (ROS) and therefore destroy bacteria [44,46]. Conjugating Au NPs with antibiotics, antimicrobial peptides (AMP), and other ligands have a tendency to enhance the antibacterial abilities, decrease the requirements of high doses, and diminish side effects [44]. Au NPs and Ag NPs were applied as drug delivery systems in antibiotics and AMPs [47]. Surface modification of the ligands can affect the antimicrobial efficiency of Au NPs [48-50]. Functionalized $\mathrm{Au}$ NPs with antibiotics or drugs show increased antimicrobial activity than antibiotics alone. In fact, Au NPs conjugated with biomolecules reduce bacterial cell growth [51]. Functionalized $\mathrm{Au}$ and Ag NPs with smaller sizes have various benefits in drug and antibiotic delivery such as regulating size and morphology, high-density surface ligands, and delivery without losing drugs which protects them from destruction [52,53].

The purpose of this article is to investigate the role of Au and Ag NPs in antimicrobial resistance and their effects. These nanomaterials are crucial in antimicrobial applications for several reasons: first, they have a large surface area, optical properties, and are made of cost-effective materials, enabling great synergy in antimicrobial actions. Second, they can target the structure of bacteria, and indications have revealed that the synergistic act of NPs and antibiotics triggered an increase in the antibacterial potential of antibiotics. We provide an overview of the unique properties of Au and Ag NPs used in the destruction and inactivation of AMR and MDR bacteria, the advance of biosensors, and their use as 
drug delivery systems, as well as addressing the challenges related to the use of these noble metals in this field and their possible solutions.

\section{Methods for the Synthesis of Au and Ag NPs}

Various methods such as biological, physical and mechanical, and chemical and photochemical can be applied to synthesize Ag and Au NPs [54] (Figure 1). A chemical assay reduces $\mathrm{Ag}^{+}$to $\mathrm{Ag}^{0}$ through a reducing agent, including sodium borohydride in the existence of a stabilizer, to preserve Ag NPs from aggregating. These reducing agents could be designated cautiously to restrict environmental influence while increasing particle stability [55].

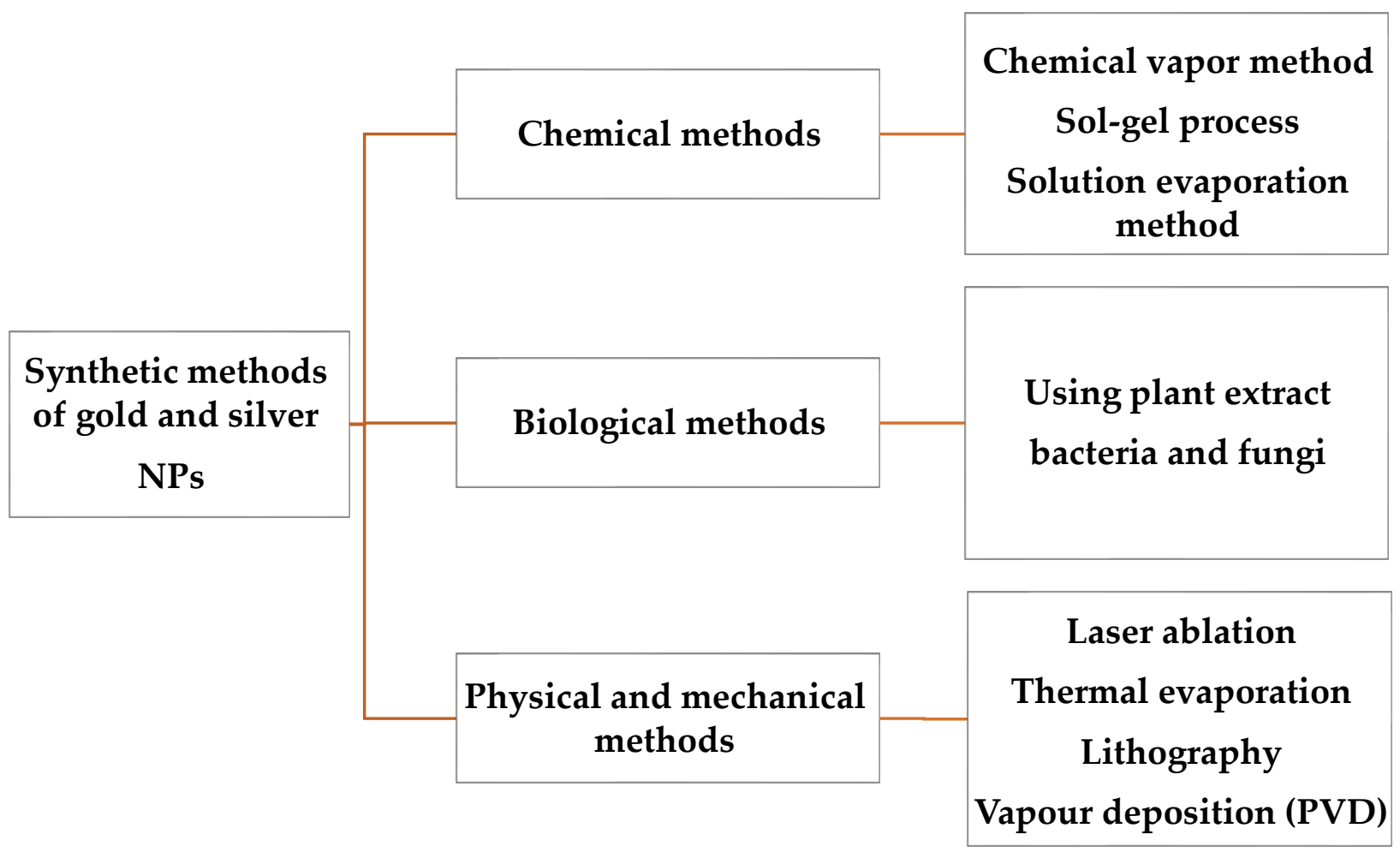

Figure 1. Various synthesis methods of Ag and Au NPs.

\subsection{Chemical Methods}

There are various methods for making Au NPs, the simplest of which is to reduce gold salt in the existence of a reducing agent [56]. The formation of Au NPs begins in the nucleus of Au ions. To avoid aggregation, a stabilizing agent is usually added through the synthesis procedure. This assay was first introduced by Turkevich in 1951 [57]. Au NPs are formed by the reduction of gold salts in water using citrate ions as a reducing agent which results in the production of spherical NPs with a diameter of $20 \mathrm{~nm}$ [58]. Sodium citrate in this process acts as both a reducing agent and a stabilizing agent through adsorption on the surface. Frances then stated in 1973 that Au NPs can be obtained in different sizes by controlling the reducing agent/stabilizing agent ratio [59]. Accordingly, Au NPs have recently been developed with the simultaneous addition of citrate salts and a surfactant such as sodium-3 mercaptopropionate [60]. Because the reactivity of NPs is very high and they tend to precipitate, a stabilizer (coating) is added to them to preserve their desirable properties [61]. Co-sputtering of $\mathrm{Au}$ and $\mathrm{SiO}_{2}$ followed by post-annealing has been reported as one of the physical methods for the fabrication of Au NPs [62]. The Brust-Schiffrin assay was developed through Brust and Schiffrin in 1994. This proved to be an easy method for the synthesis of thermally stable Au NPs of controlled size [63].

Synthesis of Ag NPs can be performed by various chemical methods, including solgel, which is one of the most common chemical methods [64,65]. However, different 
advantages and limitations were observed related to these techniques. For example, they need a high amount of energy and a tube furnace at atmospheric pressure [54]. Synthesis of Ag NPs with a size of $\sim 10 \mathrm{~nm}$ can be performed by thermal decomposition [66], lowtemperature self-agglomeration of sol-gel films [67], and sputtering/post-annealing the Ag layer deposited on a TiN buffer layer [68].

\subsection{Photochemical Processes}

Photochemical procedures can be used in the synthesis of metallic NPs, including AuNPs and Ag NPs, according to the improved temporal control these methods propose. The process involves exposing solutions comprising the metal precursors to visible or ultraviolet (UV) light. This method is beneficial as it evades the application of toxic compounds, does not need high-cost equipment, and can be performed at RT conditions as opposed to other methods, such as chemical approaches [69,70]. The photochemical procedure initiates with the reduction of the precursor of metal from $\mathrm{n}^{+}$valence $\left(\mathrm{M}^{\mathrm{n}+}\right)$ to its zero-valence state $\left(\mathrm{M}^{0}\right)$ through the photocatalyzed act of the reducing agent. Then, the $\mathrm{M}^{0}$ creates nucleation cores that grow and aggregate to provide the metallic NPs [71]. In this method, the type of light source, such as UV or visible light, and the irradiation time and application of stabilizing agents are important factors that impact the properties of the acquired NPs [72].

UV radiation with wavelength ranging from $100-400 \mathrm{~nm}$ can be used in this method. The UV-mediated photochemical synthesis of Ag and Au NPs is an effective method. It shows various properties, such as the use of water as a solvent, and the use of non-toxic capping agents that confirm NP stability. These experiments can be performed at RT conditions. In general, silver nitrate $\left(\mathrm{AgNO}_{3}\right)$ is applied as the precursor and polymers are applied as stabilizers [73,74].

\subsection{Physical Methods}

Synthesis of Ag NPs can be performed by various physicochemical methods, including laser ablation and evaporation-condensation, which are the most significant physical approaches. The uniformity of NP distribution and lack of solvent contamination in the synthesized thin films are the benefits of the physical synthesis methods over chemical methods [54].

Ag NPs could be prepared through laser ablation of metallic bulk materials. In fact, the efficacy of synthesized Ag particles is determined by various factors such as the wavelength of the laser impinging the metallic target, the liquid medium, and the period of the laser pulses [54,75].

Laser ablation can also be applied to synthesize $\mathrm{Au}$ and Ag NPs; the properties of the NPs produced rely on the laser wavelength, duration of the laser pulses, and liquid environment [76,77]. Microwave irradiation is one physical technique for the synthesis of Au NPs through reducing agents, including citric acid, and a binding agent, including cetyltrimethylammonium bromide (CTAB) [78,79]. The $\gamma$-irradiation assay is also a method for the synthesis of Au NPs with identical size of about 10 to $40 \mathrm{~nm}$ with high purity using polysaccharide alginate as a stabilizing agent [80-82]. However, techniques based on physical vapor deposition, including laser ablation, need a comparatively expensive apparatus, however, the variability of the synthesis is large, and a broader spectrum of NPs may be prepared, particularly in the case of PVD techniques where fewer chemicals are needed [83].

\subsection{Biological Methods}

The synthesis of Au and Ag NPs by green assays is more improved than chemically synthesized Ag NPs concerning antimicrobial activity. In the green synthesis method, nanoparticles in the size range of 1 to $100 \mathrm{~nm}$ are formed by bottom-up technology [84]. In this method, various types of fungi, bacteria, plants, yeasts, etc. are applied [85,86]. Recent studies show that Ag NPs synthesis using bacteria is inexpensive, easy, and attractive; these 
factors have managed to improve the number of outcomes of Ag NPs synthesis with various gram-positive and gram-negative species. The Ag NPs produced by this green method have a smaller average size, more stability, better size distribution, and higher production efficiency than the particles produced by modified microbial and polysaccharide methods. Additionally, the production time of NPs in this method is lower than the microbial method and the production cost is lower than the modified polysaccharide method $[87,88]$.

High cost and environmentally friendly assays have recently appeared mostly by biological outcomes to the synthesis of nanostructures with exclusive antimicrobial properties. To this end, the biosynthesis of Au and Ag NPs was done using the cell-free extract of red yeast Phaffia rhodozyma [89]. Conversion of metal ions to NPs in a friendly one-step method can be done by biological molecules in plant and yeast extracts.

\section{Ag Nanoparticles for Antimicrobial Resistance}

The antimicrobial effects of Ag NPs have been studied and their operative potential against a different range of microbes, including antibiotic-resistant bacteria, has been demonstrated. Dead bacteria have been observed by imaging and elemental analysis using transmission electron microscopes (TEM), vegetative electron microscopy, and EDX (X-ray Probe Micro Analyzer). Additionally, researchers have concluded that Ag NPs react with elements of bacterial cell membrane structures and lead to cell damage. Ag NPs also have antibacterial activity against gram-positive and gram-negative bacteria, but according to conflicting reports, gram-negative bacteria are more sensitive to Ag NPs than gram-positive bacteria [90-92]. Ag NPs show antimicrobial activity by various mechanisms. Ag NPs two main killing pathways are known: interaction with the microbial membrane and disruption of the functioning of the membrane. Interaction of the positively charged Ag NPs with the negatively charged bacterial cell wall can cause changes in the cell wall, resulting in increased cell permeability leading to cell death. The tendency of Ag NPs to react with phosphorus-containing sulfur molecules in extracellular cells (membrane proteins), and intracellular components (DNA and proteins) is high, which can have an important effect on cell proliferation. Moreover, the creation of reactive oxygen species (ROS) near bacteria and inside of them increases reasons for oxidative stress. The interaction of Ag NPs with the thiol group can lead to the induction of ROS, inhibition of respiratory enzymes, and apoptosis of cells [93,94].

Research has also investigated the role of Ag NPs and the mechanisms of antimicrobial activity exerted by Ag NPs (N-Ag). Efflux pumps can export the antimicrobials agents out of the cell before they can spread their target sites. Resistance to an antimicrobial agent can be acquired or inherent. Bacteria can also obtain new resistant genes from other bacteria and integrate them into their chromosomes. Therefore, due to the proliferation of multidrug-resistant microbial strains, the use of Ag NPs as an antimicrobial to control antimicrobial strains should be considered [95,96].

Different research has described the antimicrobial activity of Ag NPs against AMR microbes. The antibacterial activity of Ag NPs with a concentration range of 30-100 mmol/L were effective against erythromycin-resistant E. coli, Streptococcus pyogenes, and Pseudomonas aeruginosa (P. aeruginosa) [97].

Researchers assessed the antibacterial activity of Ag NPs on P. aeruginosa by classification of the proteomic response. Ag NPs can be activated by interaction with the membrane and the production of ROS. In fact, the higher the ROS production in the cell, the higher the oxidative damage caused by Ag NPs, so the antimicrobial activity of Ag NPs can be adjusted according to the increased release of $\mathrm{Ag}$ ions in solution [90].

Ag NPs can exhibit potent antimicrobial activity with MIC in the range of $1.4-5.6 \mu \mathrm{g} / \mathrm{mL}$ and $\mathrm{MBC}$ in the range of $2.8-5.6 \mu \mathrm{g} / \mathrm{mL}$. These nanoparticles disrupt the structure of bacteria and increase the level of alkyl hydroxide reductase which increases the production of ROS and increases apoptosis [98].

Another study exhibited the green synthesis of Ag NPs through the aqueous leaf extract of the seasonal desert plant Sisymbrium irio against different MDR bacteria. TEM 
images exhibited a particle size of 24-50 nm. According to the results, different concentrations of Ag NPs were tested against MDR P.aeruginosa and Acinetobacter baumanii and Escherichia coli (E. coli) used as controls. Ag NPs exhibited real inhibition of P. aeruginosa and Acinetobacter baumanii at the concentration of $6.25 \mu \mathrm{g}$, and the concentration of $100 \mu \mathrm{g}$ showed effective antibacterial activity on P. aeruginosa, E. coli, and Acinetobacter baumannii (A. baumannii). As a result, Ag NPs could act as operative agents to battle MDR microbes [99].

The green synthesized Ag NPs using endophytic E. hormaechei show major antimicrobial activity against B. cereus, C. albicans, S. aureus, and S. aureus. Spherical and polydispersed Ag NPs have a size of about 9-92 nm within $5 \mathrm{~min}$, and these NPs were stable with a mean $\zeta$ value of about $-19.73 \mathrm{mV}$. In this assay, Ag NPs synthesis was quick and eco-friendly; compared to traditional antibiotics, the Ag NPs were highly operative against B. cereus, showing about $9 \mathrm{~mm}$ and $8 \mathrm{~mm}$ zones of inhibition (ZOIs), respectively. These results suggest that these Ag NPs are capable antimicrobial agents that can be applied to the process and formulation of novel drugs to reduce the AMR in pathogenic and MDR microbes [11].

Researchers used Handroanthus impetiginosus extract as a reducing and capping agent in the synthesis of Ag NPs by the microwave technique. Bactericidal activity of the NPs was confirmed against $E$. coli and S. aureus establishing high inhibition possible to both bacterial strains with a MIC of $6.7 \times 10^{4} \mu \mathrm{g} / \mathrm{mL}$ and $3.1 \times 10^{2} \mu \mathrm{g} / \mathrm{mL}$, respectively, though the extract showed a low MIC in both bacteria. Remarkably, the bactericidal activity of Ag NPs is greater in S. aureus than E. coli. This was related to the mixture of Ag NPs with the capping layer comprising natural compounds with antimicrobial characteristics and showing high antibacterial effects compared to gram-negative strains [100].

Ag NPs can be applied in the inhibition and killing of planktonic bacteria, as well as successfully inhibiting biofilm formation [101]. Although, naked Ag NPs have a tendency to aggregate because of their great surface energy resulting from their large specific surface area they most certainly oxidize in storage [102]. However, different Ag NP-based composites have been synthesized including magnetic NPs (MNP)@Ag NPs, CNT-Ag NPs [103], graphene oxide(GO)-Ag NPs, and $\mathrm{TiO}_{2}-\mathrm{Ag} \mathrm{NPs}[104,105]$ which can increase the permanency of Ag NPs, and offer antibacterial and antibiofilm effects other than naked Ag NPs [106]. In addition, it has been reported that by using electric field stimulation, the antibacterial activity of Ag nanostructures can be increased significantly [107].

The use of Ag NPs to prevent biofilm has been reported in several studies. Ag NPs synthesized using Streptomyces strains the size of 10-30 nm showed the ability to inhibit the growth of pathogenic strains such as methicillin-resistant tetracycline-resistant Neisseria gonorrhoeae and Staphylococcus aureus (S. aureus). It also reduced biofilm production by Pseudomonas aeruginosa by $80 \%$. Another use of these nanoparticles can be using Ag NPs as a coating material on medical devices used to treat patients to prevent the creation of biofilms [108].

Spherical Ag NPs with a size of $30 \mathrm{~nm}$ showed high ability in preventing P. aeruginosa biofilm. Biofilm can be more resistant to Ag NPs compared to planktonic cells. If a high concentration of Ag NPs, about $18 \mu \mathrm{g} / \mathrm{mL}$, were used, biofilm development was fully prevented. However, low doses of AgNPs can be late in preventing the growth cycle of biofilm. Additionally, sublethal doses of Ag NPs improved the manufacture of proteins and polysaccharides compared to a control, which meaningfully changed the biofilm structure [109].

High antimicrobial activity was shown by Ag NPs synthesized by Terminalia catappa leaf extract (TCE) via a one-pot single-step assay (TCE-Ag NPs) with different concentrations. Various concentrations of TCE have produced altered-sized Ag NPs. TCE-Ag NPs-3 show effective prevention of the biofilm formation of methicillin-resistant $S$. aureus (MRSA) and multi-drug-resistant P. aeruginosa (MDR-PA) by about $70 \%$ and $73 \%$, respectively, at a concentration of about $8 \mu \mathrm{g} / \mathrm{Ml}$. The results suggest that the treatment of $100 \mu \mathrm{L}$ of TCE-Ag-1 can suppress the development of MRSA, MDR-PA, and C. albicans of about 11, 19 , and $14 \mathrm{~mm}$, respectively. Moreover, the diameters of growth inhibition zones with 
TCE-Ag-2 were initiated to be 12, 20, and $15 \mathrm{~mm}$ against MRSA, MDR-PA, and C. albicans, respectively. Additionally, the diameters of growth inhibition zones with TCE-Ag-3 were about 14-, 21-, and 17-mm in diameter against MRSA, MDR-PA, and C. albicans, respectively. These NPs can destroy the membranes of MDR-PA, MRSA, and C. albicans [110].

The combination of Ag NPs with organic molecules shows improved antimicrobial activity. For example, lignin, a hydrogel formulated with Ag NPs, was produced. The product exhibited great antimicrobial activity against S. aureus with about $100 \%$ of the bacteria killed after several hours of treatment. The platform showed high biocompatibility with L929 cells [110]. (Bio)-polymers can increase the antimicrobial activity of Ag NPs [111,112]. Chitosan was an appropriate polymeric material to encourage Ag NPs capping, which shows excessive microbial probability and decreases cytotoxic effects. Ascorbic acid chitosan and ascorbic acid were used as the capping agent and reducing agent, respectively, and were applied for the synthesis of Ag NPs with small size $(<10 \mathrm{~nm})$. The loading of Ag NPs and other agents onto the coating can release the molecules and kill pathogens. For example, the synthesis of chitosan -ascorbic acid-Ag nanocomposites was developed. It was established that the nanocomposites showed an important microbial activity against the S. aureus, E. coli, and P.aeruginosa, as well as the inhibition of biofilm development. These nanocomposites also showed a reduction in the induction of cytotoxicity in mammals. However, further doses of potential toxicity and drug resistance need to be investigated [111]. In general, controlled release can be a significant and efficient assay to prevent biofilm formation. Furthermore, in the formation of biofilm, the use of chitosan alone would not be suitable.

Using chitosan and brown algae extract, researchers synthesized Ag NPs that exhibited improved bactericidal activity against Bacillus cereus and Salmonella enterica. The antibacterial evaluations showed that Ag NPs synthesized with a combination of algae extract and chitosan showed greater bactericidal activity with ZOI values greater than $16 \mathrm{~mm}$ in all bacteria, although ZOI values of Ag NPs or extract alone were lower [113]. In general, Ag NPs with chitosan were incorporated throughout their synthesis procedure, and the formulations produced based on the NPs showed high antibacterial capacity.

An interesting point in this regard is the mixture of Ag NPs with antibiotics to improve antimicrobial activity. Katva et al. exhibited that the mixture of gentamicin and chloramphenicol with Ag NPs show a high antibacterial effect in MDR E. faecalis [114]. In another study, researchers exhibited that Ag NPs combined with other antibiotics can show a synergistic effect, displaying an improved antibacterial activity at concentrations less than the MIC of NPs or the antibiotic [115].

The use of Ag NPs is also involved in industry and commerce due to their antimicrobial properties. The use of Ag NPs in face masks can help improve their protective ability. A study by Li and a colleague showed the production of masks coated with Ag nitrate and titanium dioxide nanoparticles that were able to reduce up to $100 \%$ of S. aureus and E. coli in one day. As a result, the use of Ag NPs face masks can prevent infection in places, e.g., hospitals, where there is a high persistence of pathogenic microorganisms [116].

In general, Ag NPs show high antimicrobial activities. They address various conditions to which novel antimicrobial technologies are emerging and can be operative concerning antimicrobial activity and low cytotoxicity. The application of the Ag NPs reduces the doses of the antibiotic and the nanoparticle needed to attain an operative antibacterial activity against various MDRs microbes. These NPs can form complexes to perform as nanocarriers of antibiotics that improve their release and enhance their antibacterial outcome. Table 1 shows other examples of the application of Ag NPs in antimicrobial resistance activity (AMR). 
Table 1. Other examples of the application of Ag NPs in antimicrobial resistance activity (AMR).

\begin{tabular}{|c|c|c|c|c|}
\hline Bacteria & Type of NPs & Size (nm) & Description & Ref. \\
\hline E. coli & Ag NPs & $30 \mathrm{~nm}$ & $\begin{array}{l}\text { The EC50 of the Ag NPs against } \\
\text { E. coli was about } 11 \mathrm{mg} / \mathrm{L} \text {. }\end{array}$ & [117] \\
\hline E. coli and Vibrio cholerae & Ag NPs & $\sim 30 \mathrm{~nm}$ & $\begin{array}{l}\mathrm{Ag} \text { NPs were verified as the MIC } \\
\text { against } V . \text { cholerae and E. coli. }\end{array}$ & [118] \\
\hline P. aeruginosa, E. coli, S.aureus & Ag NPs & $140 \mathrm{~nm}$ & $\begin{array}{c}\text { Ag NPs show antimicrobial } \\
\text { activity against gram-positive } \\
\text { (1500 ppm) and gram-negative } \\
\text { bacteria (125 ppm.) }\end{array}$ & [119] \\
\hline K. pneumoniae & Ag NPs & $5.2 \pm 1.2 \mathrm{~nm}$ & $\begin{array}{l}\text { Ag NPs can induce triclosan-like } \\
\text { antibacterial action against } K \text {. } \\
\text { pneumonia. }\end{array}$ & [120] \\
\hline $\begin{array}{l}\text { S. marcescens, P. aeruginosa, } \\
\text { C. violaceum }\end{array}$ & Ag NPs & $5-20 \mathrm{~nm}$ & $\begin{array}{l}\text { The Ag NP inhibition rate of } 87 \% \text {, } \\
81 \% \text {, and } 71 \% \text { for biofilms of } \\
\text { C. violaceum, S. marcescens, and } \\
\text { P. aeruginosa, respectively. }\end{array}$ & [121] \\
\hline E. coli and Staphylococcus aureus & Ag NPs & $12 \mathrm{~nm}$ & $\begin{array}{l}\text { Ag NPs show a great antimicrobial } \\
\text { activity against } E \text {. coli, with a MIC } \\
\text { of about } 120 \mu \mathrm{mol} / \mathrm{L} .\end{array}$ & [122] \\
\hline S. aureus & Ag NPs & $27 \mathrm{~nm}$ & $\begin{array}{l}\text { The green synthesis of Ag NPs can } \\
\text { be used for the inhibition of } \\
\text { S. aureus. }\end{array}$ & [123] \\
\hline P. aeruginosa, E. coli & $\begin{array}{l}\text { TGA-stabilized } \\
\text { AgNPs }\end{array}$ & $16-25 \mathrm{~nm}$ & $\begin{array}{c}\text { Vancomycin-AgNPs can improve } \\
\text { antibacterial activity against } \\
\text { gram-positive bacteria. }\end{array}$ & [124] \\
\hline S. pneumoniae & Ag NPs & $63.65 \pm 12.71 \mathrm{~nm}$ & $\begin{array}{l}\text { The NP coated antimicrobial } \\
\text { medical devices to battle against } \\
\text { MDR infection. }\end{array}$ & [125] \\
\hline P. aeruginosa & Ag NPs & $\sim 2.4,13.92 \mathrm{~nm}$ & $\begin{array}{l}\text { The NPs can be used to evade } \\
\text { multidrug efflux pumps. }\end{array}$ & [126] \\
\hline A. baumannii & TMCN-Ag NPs & Less than $60 \mathrm{~nm}$ & $\begin{array}{l}\text { The NPD connect to the cell wall } \\
\text { causing changes in the } \\
\text { permeability of the cell membrane. }\end{array}$ & [127] \\
\hline
\end{tabular}

MIC: Minimum inhibitory concentration, NPs: Nanoparticles, TMCN: Trimethylchitosan.

\section{Gold Nanoparticles for Antimicrobial Resistance}

Unlike Ag, which has strong antimicrobial properties, Au is not recognized as having an inherent antimicrobial property. Although, the characteristics of nanoscale Au NPs can provide strong particle performance and scientists have discovered the possibility of using $\mathrm{Au}$ NPs in biofilm treatment. Au NPs can be synthesized by reducing gold salts through several completely fixed methods [128,129]. Moreover, Au NPs can also be synthesized by reducing gold salts through several completely fixed methods $[128,129]$. In recent years, $\mathrm{Au}$ NPs have been applied in various fields according to their optical properties and surface plasmon resonance [30,58].

The antimicrobial activity of Au NPs has developed a significant research area according to their exclusive physicochemical properties [130]. The use of chemicals and drugs can cause problems as therapeutic agents, including low specificity, insufficient cell penetration, and short half-life. Many of these problems can be solved in combination with Au NPs. For example, the improvement of the anti-angiogenic activity of MCF-7 cells by kaempferolbounded Au NP compared to kaempferol alone [131].

The functionalized Au NPs with small molecules can provide improved bioavailability, stability, and biocompatibility than the carriers alone. Several irregular-shaped Au NPs 
can simply adsorb molecules on their surface, display a worthy plasmon resonance, and be used in the recognition of cancer cells [132]. The capping of Au NPs with vanillin (VAuNPs), which is synthesized by green assay, is used as an inhibitor of MexAB-OprM efflux pump components (Figure 2). Although VAuNPs show non-bactericidal effects at high concentrations, the antibiotic potential was considered in combination with seven applied antibiotics in contradiction of P. aeruginosa. The results showed that if about $50 \mu \mathrm{g} / \mathrm{mL}$ of VAuNPs were used, a decrease in the inhibitory concentrations of the antibiotics trimethoprim and meropenem was detected by 10 and 14 times, respectively. Au NPs in a mixture with trimethoprim and meropenem can also provide effects about 3-times better than naked vanillin. The results also show that the activity of the output pumps is blocked by VAuNP. Therefore, the large decrease in MIC of antibiotics was attributed to the suppressive activity of the VAuNPs outlet pump. It was stated that VAuNP increases sensitivity to the antibiotics meropenem, trimethoprim, and others. In general, the capability of VAuNPs and vanillin to be applied as antibiotic adjuvants to inhibit bacterial outflow pumps is used to boost antibiotics and address the AMR that affects human health and the environment [43].
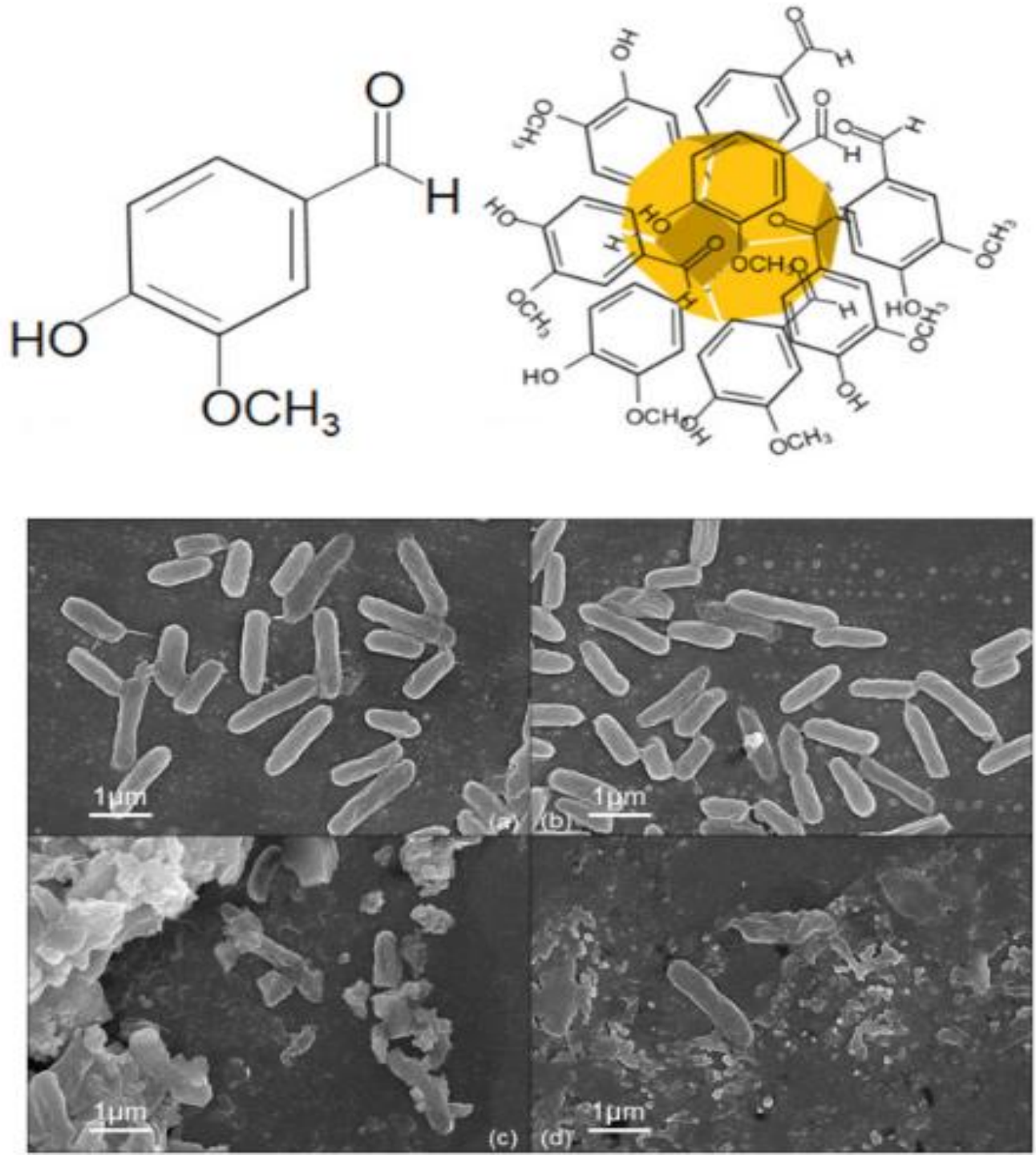

Figure 2. Schematic illustration of synthesized VAuNPs by vanillin (the above illustration); FESEM image of $P$. aeruginosa in untreated, in presence of the (a) $50 \mu \mathrm{g} / \mathrm{mL}$ of VAuNPs, (b) Meropenem$200 \mu \mathrm{g} / \mathrm{mL}$, (c) Meropenem $(20 \mu \mathrm{g} / \mathrm{mL})$ and (d) VAuNPs $(50 \mu \mathrm{g} / \mathrm{mL})$ (the below images) [43]. Reprinted with permission from Elsevier. 
Antimicrobial peptides (AMPs) are debated as elegant substitutes to traditional antibiotics in the battle against multi-drug resistance pathogens which can kill pathogenic bacteria, fungi, and protozoa, according to the broad-spectrum of activity [133-135]. Gu and colleagues, first reported the binding of AMPs bound to metal nanoparticles, such as $\mathrm{Au}$, and exhibited that vancomycin bound to Au NPs (Au@Van) through thiol bonds can be active against vancomycin-resistant enterococci [136].

The conjugation of AMP with Au NPs via a polyethylene glycol (PEG) linker shows the high anti-P. aeruginosa activity of free esculentin-1a through 15-fold without being toxic to human keratinocytes [137]. In this study, researchers used frog skin AMP esculentin1a(1-21)NH2 with a durable activity against clinical samples of P. aeruginosa. If Eu (1-21) Au NP was used against $P$. aeruginosa, these nanoplatforms showed their antibiofilm properties, and almost half of the biofilm was destroyed within $2 \mathrm{~h}$ of treatment with the peptide concentration. The results indicate the high antibacterial activity of AMP esculentin-1a, which binds to Au NPs through PEG, then free peptides. This is likely according to the significant amount of Esc (1-21) present in the Au NPs at the PEG surface, nevertheless due to its orientation, and the great concentration of Au NPs@Esc (1-21) in the bacterial surface in addition to its long-term bioavailability. As a result, Au NPs@Esc (1-21) illustrate a disruption of the membrane as a significant assay for killing microbes [137] (Figure 3).
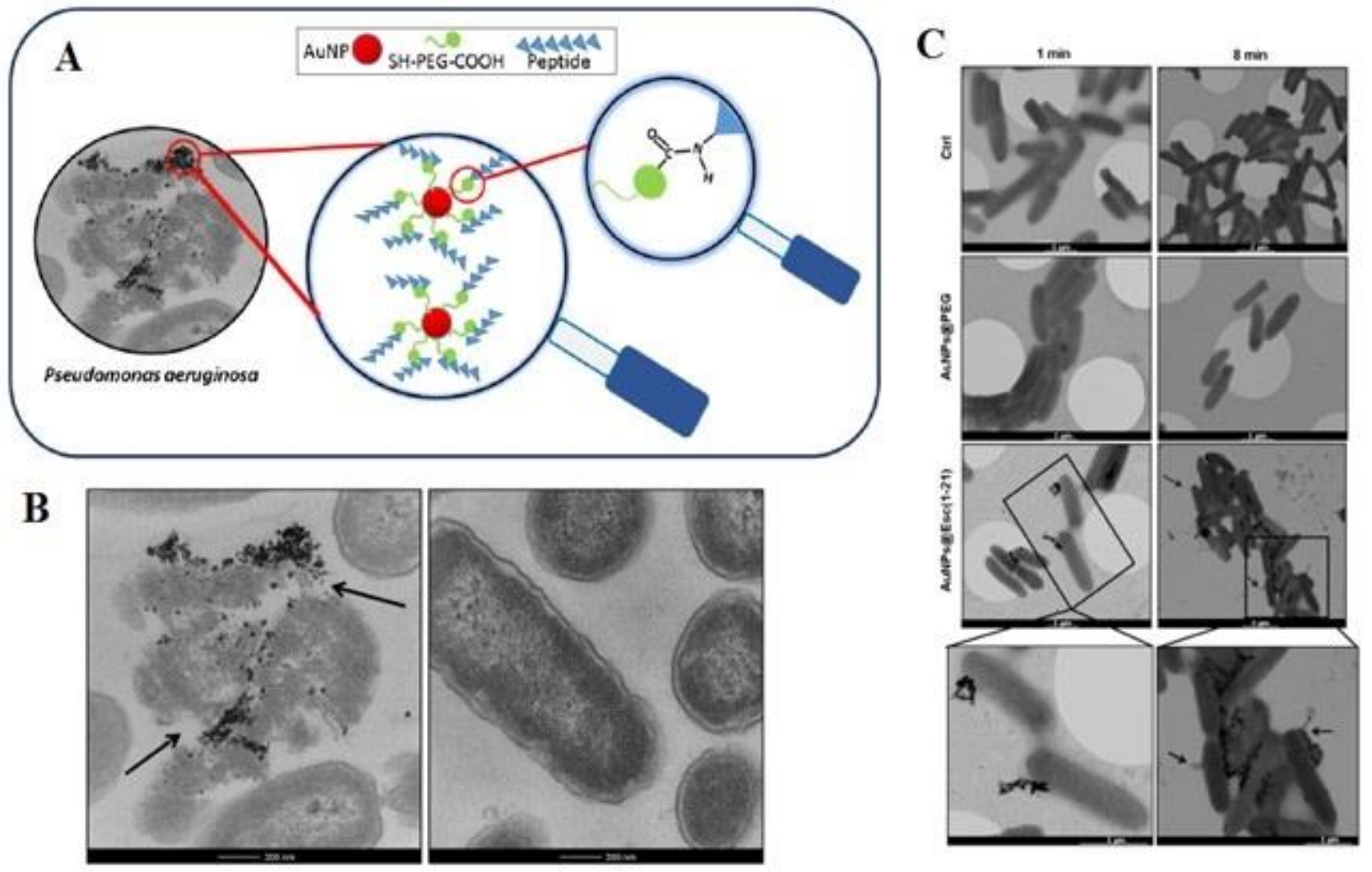

Figure 3. (A) Image of Esculentin-1a (1-21)-NH2 coated Au NPs and its interaction with bacteria. (B) Treatment of P. aeruginosa with (left) Au NPs@Esc(1-21) and (right) buffer as a control. (C) Schematic of P. aeruginosa cells treatment with Au NPs@Esc(1-21), Au NPs@PEG, and buffer [137]. Reprinted with permission from Elsevier.

Au NPs can also be used in AMP delivery and validate the significance of their roles in gene and drug delivery applications. The conjugation of Au NPs with DNA aptamer shows effectively delivered AMPs into mammalian cells to prevent $S$. typhimurium colonization in mouse subjects [138]. Additionally, the conjugation of AMPs with Au NPs can bring together genes into stem cells [139]. 
In general, about 70 fungi and bacteria are described to be related to oral disease. Au NPs with a size of approximately $30 \mathrm{~nm}$ synthesized by green assay through Justicia glauca, displays an antagonistic outcome with Clarithromycin and Azithromycin antibiotics in contradiction of oral pathogenic bacteria and fungi, such as Streptococcus mutans, Bacillus subtilis, Staphylococcus aureus, Saccharomyces cerevisiae, Lactobacillus acidophilus, and E. coli. The Au NPs and drug conjugated Au NPs exhibited possible antimicrobial action against the oral pathogens. Minimum Inhibitory Concentration (MIC) principles of Au NPs were detected in the range of about $6-25 \mu \mathrm{g} / \mathrm{mL}$ against oral pathogens. Bacterial cell membranes have hydrophobic properties that prepared glycoproteins and phospholipids may help drug-loaded Au NPs transfer through the membrane. In fact, the interaction of NPs with bacteria can inhibit the growth of bacteria through the growth signaling pathway. These green synthesized Au NPs show the high efficiency of anti-microbial activity of NPs in AMR (Figure 4A) [134,140-142].

The use of nanomaterials such as Au NPs, silica NPs, etc. for controlled antibiotic delivery have several advantages including the reduction of toxicity, drug solubility improvement, and lower antibiotic dosage $[143,144]$. The preparation of carriers containing $\mathrm{Au}$-silica core-shell mesoporous NPs (Au@MNs) and silica mesoporous NPs, loaded with amoxicillin (Amox) and ofloxacin was applied against P. aeruginosa, E. coli, and MRSA. The loading potential of these nanocarriers was assessed towards ofloxacin and amoxicillin antibiotics, and a great encapsulation of 70\% (Au@MNs) and 62\% (MNs) were reached in comparison to amoxicillin. Both Au@MNs and silica mesoporous NPs presented an important role in the actual delivery of amoxicillin for P. aeruginosa and MRSA. Decreases of 10 times (Amox@MNs) and 20 times (Amox@Au@MNs) in the quantity of antibiotics to P. aeruginosa; and a decrease of about 20 times (Amox@MNs) to MRSA was associated with a decline of resistance and finds these carriers capable of attacking AMR [145].

Since the unintended constant contact of bacteria with antibiotics in the environment increases AMR, one of the solutions in the fight against AMR is the detection of antibiotics in the environment that can be used to treat bacterial infections in humans. AMR in humans is powered through empirical infection diagnostics and unintended antibiotics revelation [146].

Au NPs have been recognized as outstanding properties in LSPR biosensors according to the spectral response to the NPs surface, and the simplicity of observing the signal of light according to their absorption and durable scattering [147]. An optical fiber biosensor based on LSPR for the capture of P. aeruginosa and E. coli monitored by antibiotic refereed lysis has been revealed in rapid drug susceptibility testing. P. aeruginosa RS1 may be sensitive to the third generation of ceftazidime, cephalosporins, and cefotaxime. P. aeruginosa can be immobilized on Au NPs in the quantification of cephalosporins with a range of $0.01-1 \mu \mathrm{g} / \mathrm{mL}$ and LOD was established to be $0.5 \mu \mathrm{g} / \mathrm{mL}$ in human serum. This biosensor can act as a substitute to mass spectrometry and chromatography methods for the cheap and rapid detection of antibiotics using the optical properties of Au NPs (Figure 5) [146].

$\mathrm{Au}$ is an inert and rare metal to microbes. However, ionic $\mathrm{Au}(\mathrm{Au}+$ and $\mathrm{Au} 3+)$ shows high antimicrobial activities. The antibacterial effect of ionic gold against various bacteria such as Salmonella typhiurium, S. aureus, and E. coli was shown by Dasari and colleagues [148]. $\mathrm{Au}^{+}$with an $\mathrm{IC}_{50}$ range of about $0.30-0.50 \mu \mathrm{M}$ and $\mathrm{Au}^{3+}$ with $\mathrm{IC}_{50}$ range of $0.320-0.50 \mu \mathrm{M}$ were found to be greatly toxic to these bacteria. Ionic gold shows antimicrobial activity against $P$. aeruginosa with various AMR profiles. The combination of disc diffusion assays with the smallest inhibitory / bactericidal concentrations (MIC/MBC) were used to regulate the antimicrobial efficiency of ionic gold. Ionic gold at increasing concentrations shows improved antimicrobial activity and antimicrobial values against all strains tested. In fact, ionic gold can be used as a different antimicrobial agent against AMR P. aeruginosa [149]. Au NPs are modified, and these modified Au NPs can improve their antibacterial properties in antibacterial use. They can also be used as drug nanocarriers to enhance drug efficiency, and their thermal properties can be assembled to kill microbes. 


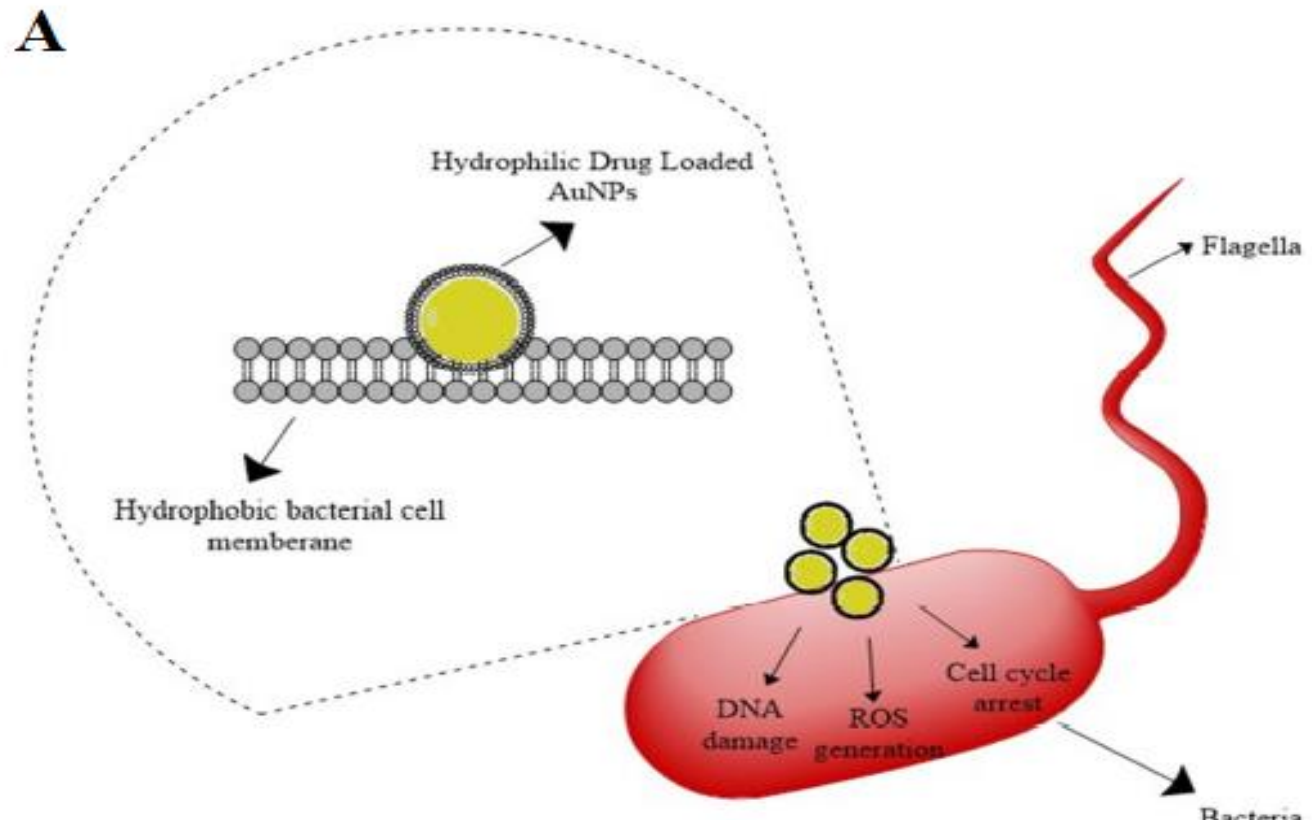

\section{B}
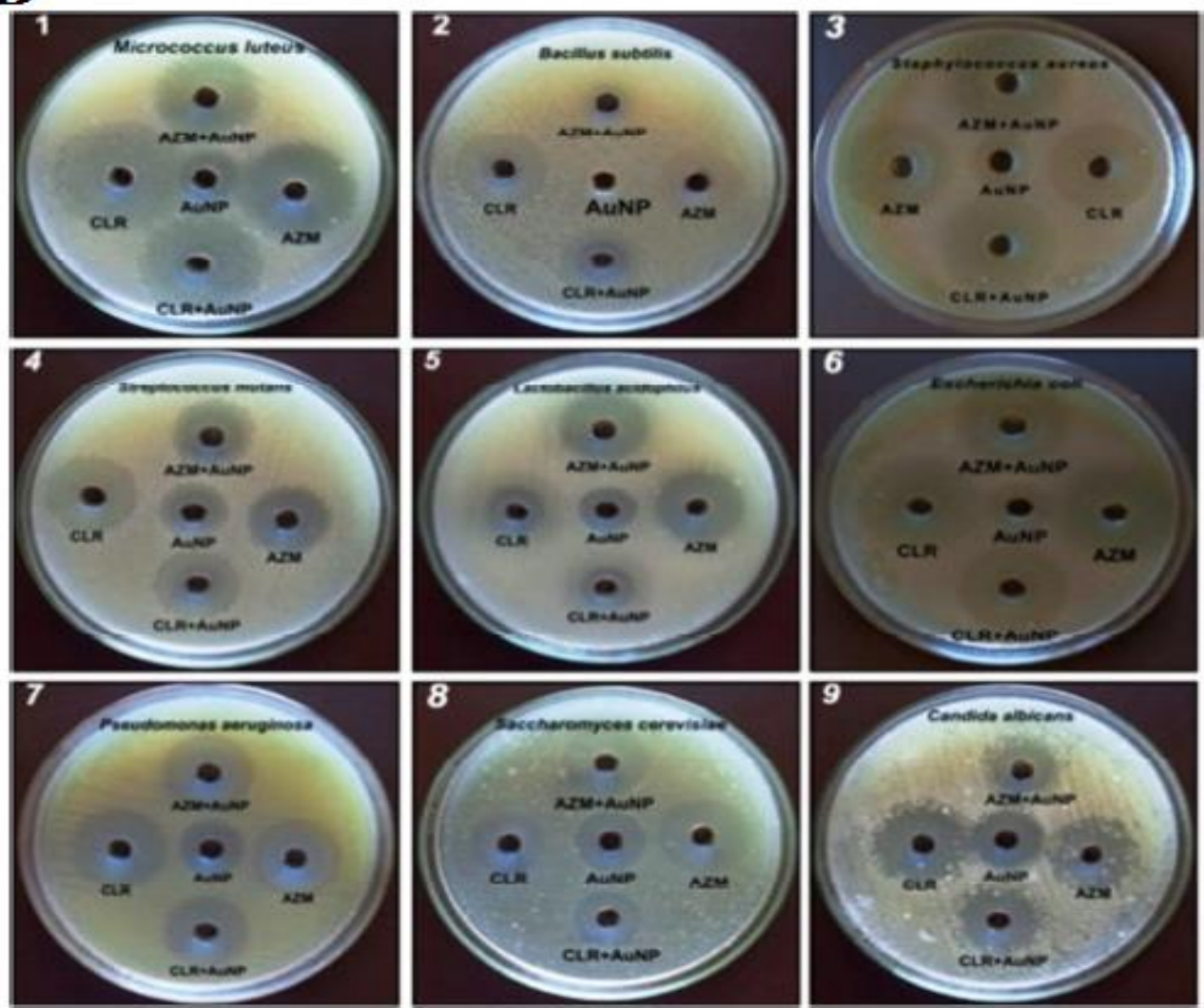

Figure 4. Schematic illustration of the killing of bacterial cells by Au NPs (A); schematic of spectrum antimicrobial activity of Au NPs, naked drug, and drug-loaded Au NPs against oral pathogenic pathogens. (B) The AuNPs $(100 \mu \mathrm{g})$ and drug-AuNPs show a wide-spectrum antimicrobial effect against the pathogens. AuNPs exhibited antimicrobial activity through the creation of a zone of inhibition ranging from about $17 \mathrm{~mm}$ against pathogens excluding $B$. subtilis, which shows less of a response with a $9 \mathrm{~mm}$ zone [140]. Reprinted with permission from Elsevier. 
(a)

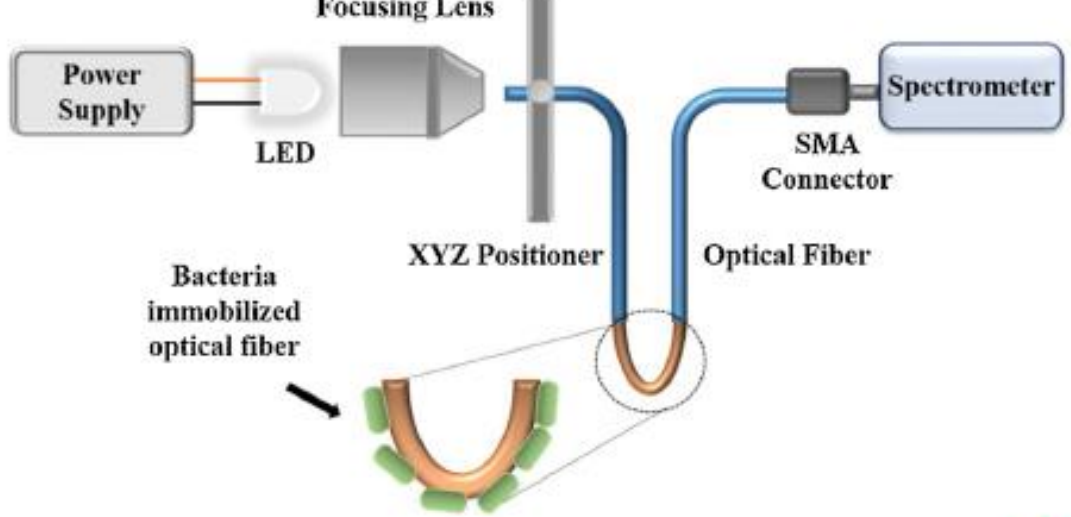

(b)
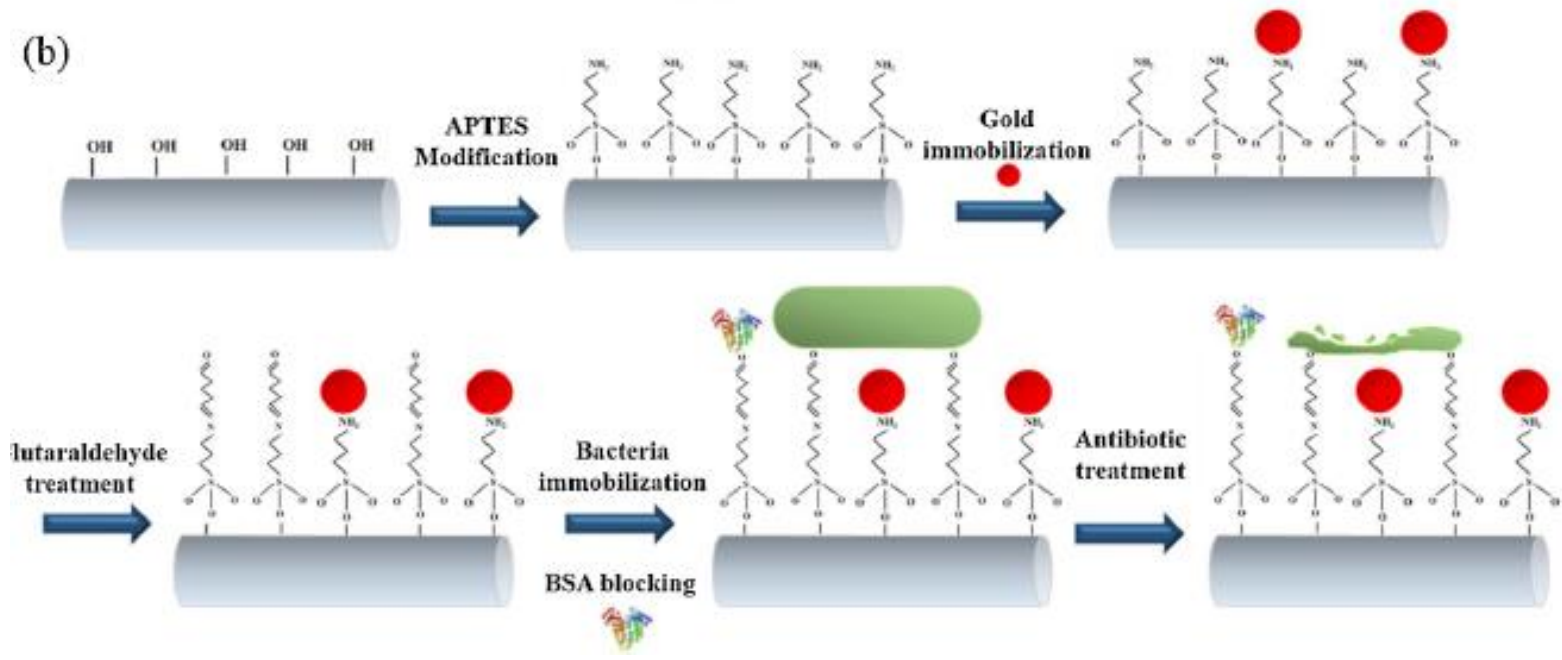

Figure 5. Schematic of an optical and sensing detection assay for the third generation of antibiotics through bacterial cells, (a) Optical detection assembly (b) The biosensing mechanism of antibiotics with bacterial cells [146]. Reprinted with permission from Elsevier.

The photothermal and photodynamic properties of AuNPs are a foundation in their medical applications [150]. Photothermal therapy (PTT) acts through irradiating Au NPs using a laser source to create heat. This heat damages neighboring bacterial cells [151]. Gold nanorods (AuNRs) and nanostars (AuNSTs) are examples applied in the PTT assay in biofilm abolition [152,153]. An antibacterial PTT using a phospholipid-decorated gold nanorod (DSPE-AuNR) was developed against P. aeruginosa biofilm. Results exhibited about a $6 \log$ cycle reduction of the viable bacterial count with the treatment of P. aeruginosa with DSPE-AuNR after laser irradiation. The results show important changes in the shape of the bacterial membrane using the DSPE-AuNR. These results suggest that the heat produced with DSPE-AuNR excitation is accountable in the lysis of bacteria in biofilm cultures, though the probable contribution of the AuNRs themselves to the detected antibacterial effect should not be omitted [154].

In another study, the antibacterial activity of a chitosan-based hydrogel with embedded gold nanorods (Ch/AuNRs) under laser irradiation was developed. The antibacterial activity was evaluated on MDR strains. The results exhibited antibacterial activity of the Ch/AuNRs with MICs of $4 \mu \mathrm{g} / \mathrm{mL}$, and low toxicity with cell viability of $80 \%$ after testing against a model of macrophage cells. This antibacterial activity is an effect of singlet oxygen production as well as the estrangement and the autolysis of bacterial membranes [155].

The macrophage membrane-coated system can be applied in medicine by bacterial pretreated macrophage membranes in precise bacterial recognition. A system was established through research by which $S$. aureus treated macrophage membranes were connected to $\mathrm{Au}-\mathrm{Ag}$ nanocages making the conjugate Sa-M- GSNC. This nanosystem presented several 
benefits such as: 1 . The capability to adhere to bacterial cells in therapy; 2 . The use of the photothermal effect, which caused considerably decreased bacterial counts; and 3. High biocompatibility and blood circulation time when established on mice [156].

Silica-coated $\mathrm{Au}-\mathrm{Ag}$ nanocages under NIR laser exhibited improvements in bacterial resistance. Coating the $\mathrm{Au}-\mathrm{Ag}$ nanocages with silicon dioxide enhanced the plasmon resonance of the $\mathrm{Au}-\mathrm{Ag}$ nanocages (Figure 6). In this study, under irradiation of $\mathrm{Au}-\mathrm{Ag} @ \mathrm{SiO}_{2}$ nanocages with a NIR laser, there was a temperature increase. It was observed that the rise in the concentration of nanocages and the time of irradiation was associated with an increase in temperature. The results indicated that the heat formed through this nanoplatform was quick and capable of removing S. aureus, Enterobacter spp, K. pneumoniae, and P. aeruginosa [157].

A

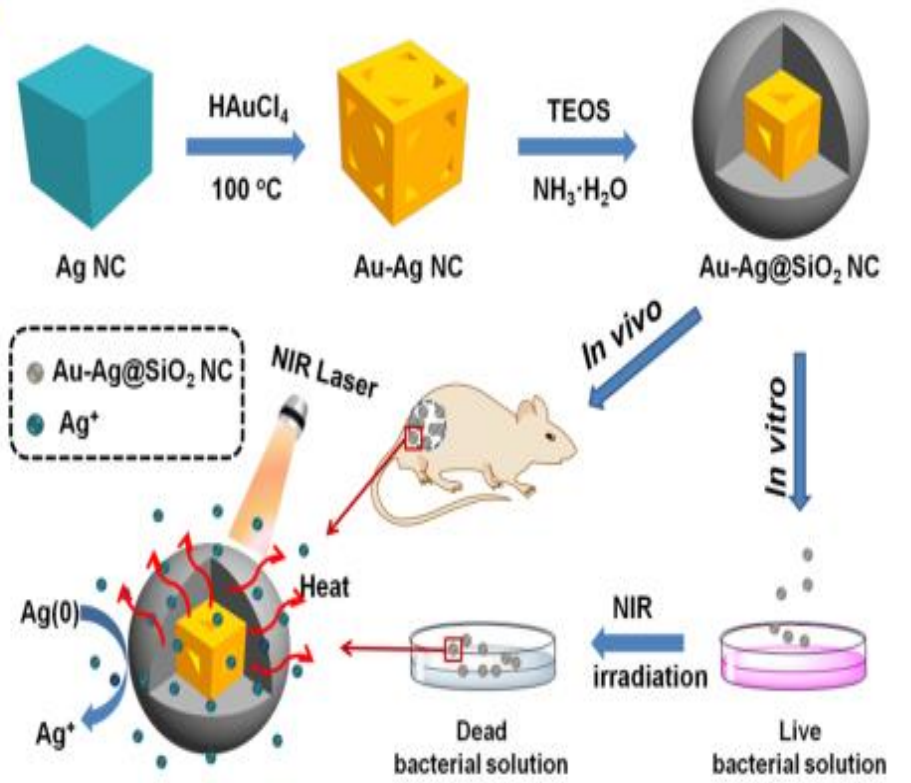

B
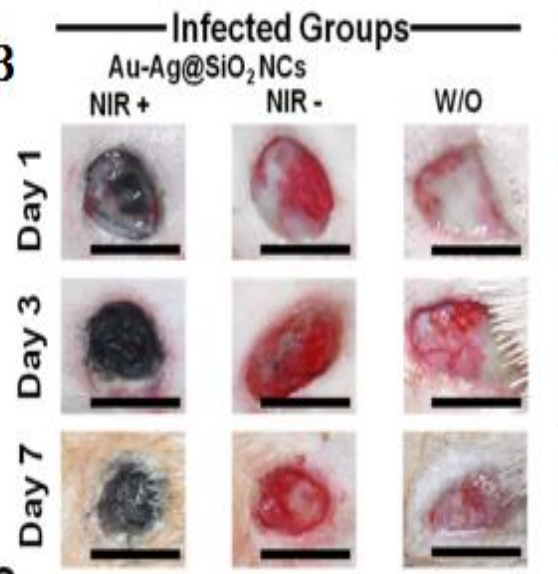

C

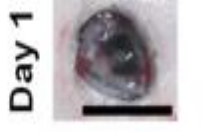

กั
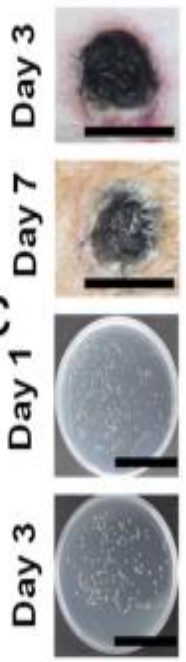

กิ

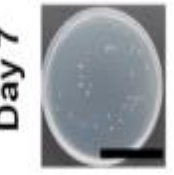

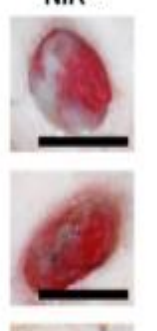

Control
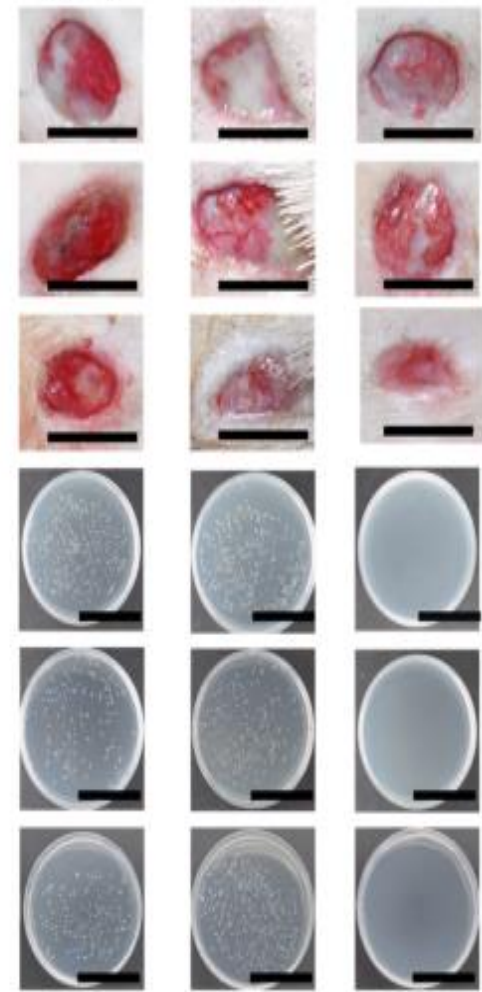
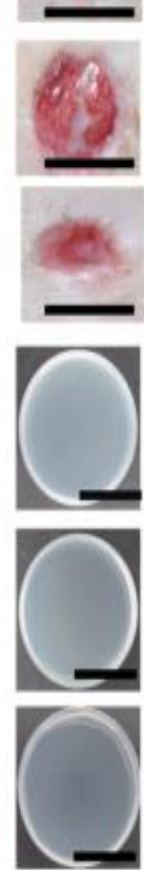

Figure 6. Schematic illustration of the Silica-coated Au-Ag nanocages displays antibacterial activity through photothermal activity (A). Schematic of wound tissues with various treatments on three days (B). Photographs of bacterial colonies from tissues of various treatment groups (C) Reprinted with permission from [157]. Copyright 2022 American Chemical Society.

Researchers established a photodynamic antibacterial delivery system comprised of ConA directed dextran-capped Au NPs (GNPDEX-ConA) conjugated to PS MB establishing the MB@GNPDEX-ConA. This platform enhanced the efficiency of MB-induced killing of MDR clinical isolates, such as Klebsiella pneumoniae (K. pneumoniae), E. coli, and Enterobacter cloacae. With photothermal activation, this method was capable of destroying about $95 \%$ of MDR bacteria and exhibited no toxic effects as confirmed with HEK293 cells. ConA and dextran assisted in the connection of this conjugate to the bacterial surface and then bacterial surface lipopolysaccharides, as revealed in Figure 7. Single oxygen created through the conjugated $\mathrm{MB}$ after photoactivation was mostly accountable in the bacterial abolition. The results showed that the existence of MB in near contiguity to the Au NPs improved the production of singlet oxygen and improved the antibacterial abilities [158]. 
A
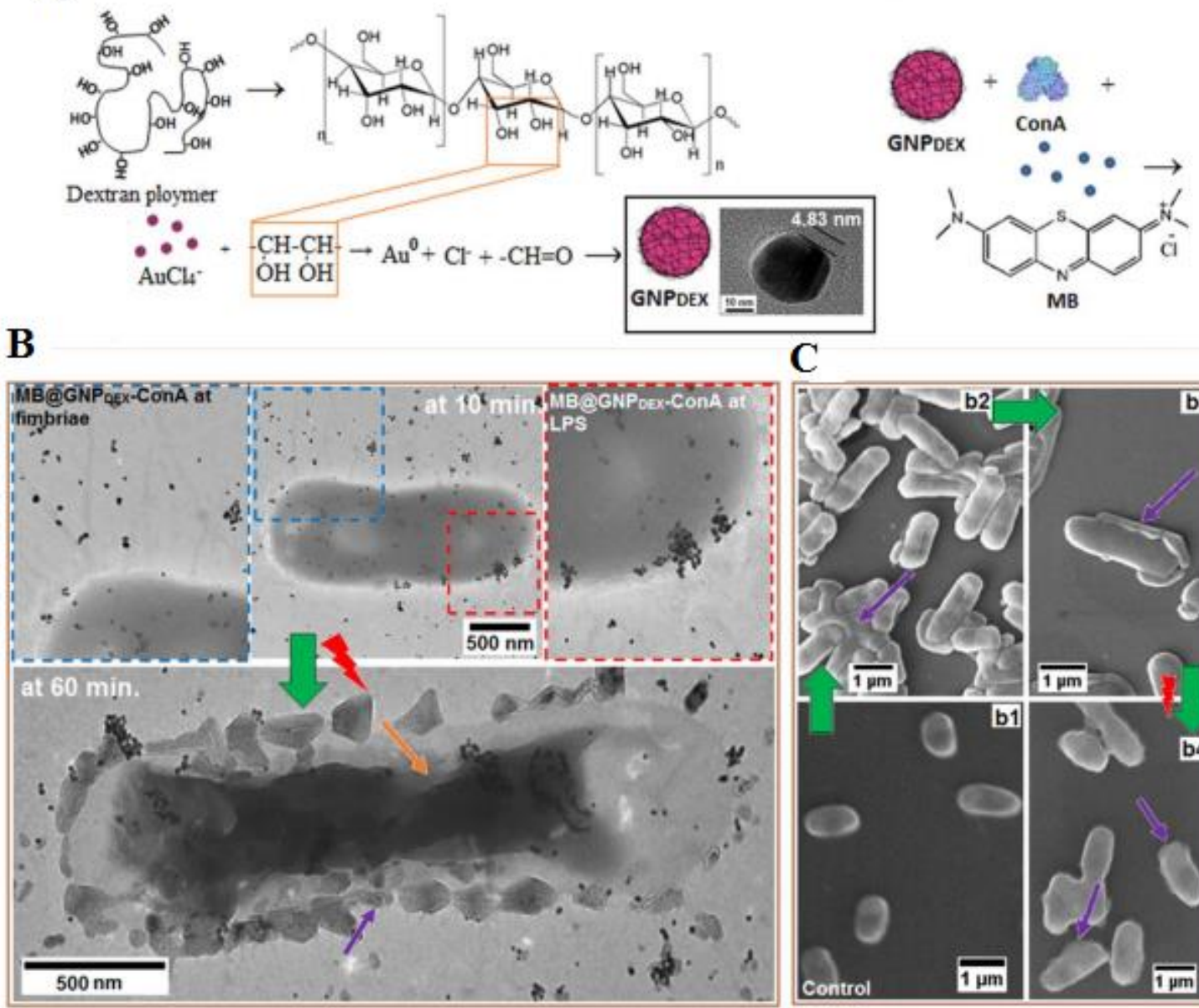

\section{C}
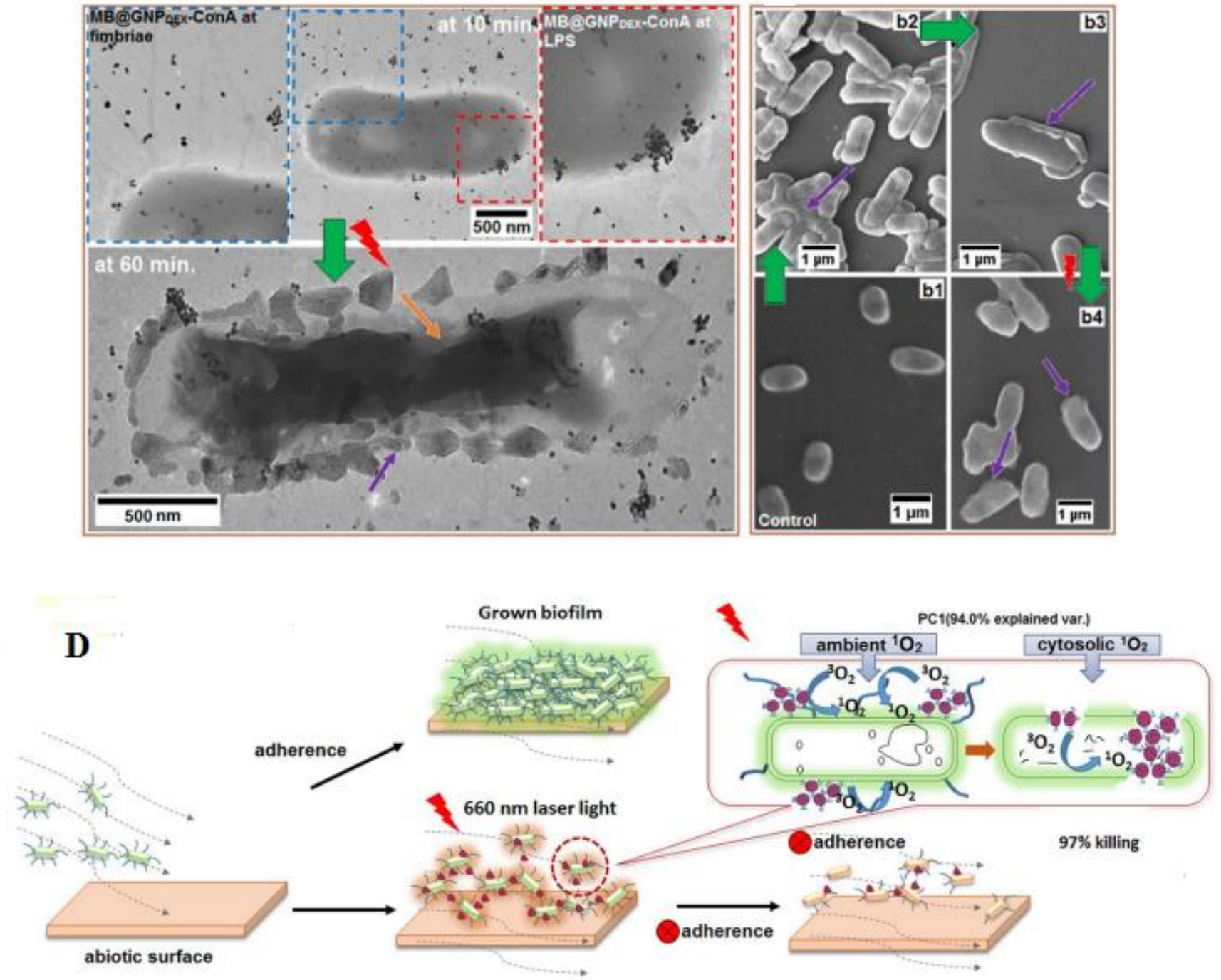

Figure 7. Schematic representation of the synthesis of dextran capped AuNPs (A). TEM image of localized MB@GNPDEX-ConA on K.Pneumoniae-12 bacterial surface and treatment. The schematic displays the cytological mass with accumulated conjugates (yellow arrow) and cell surface discomposure (B). The uniform morphology of bacterial aggregation and control cells according to concanavalin A (ConA)-mediated connection of conjugates $(\mathbf{C})$. With light irradiation, the singlet oxygen produces ambient ${ }^{1}$ and cyto $\mathrm{O}_{2}$, however, the cytosolic singlet oxygen influence the bactericidal effect and the absence of adherence through ambient oxygen. Singlet oxygen around the bacterial cells decreases the adherence ability (D) [158] Reprinted with permission from Elsevier. Table 2 displays other examples of the application of Au NPs in antimicrobial resistance activity (AMR). 
Table 2. Other examples of the application of Au NPs in antimicrobial resistance activity (AMR).

\begin{tabular}{|c|c|c|c|c|}
\hline Bacteria & Type of NPs & Size (nm) & Description & Ref. \\
\hline S. aureus, E. coli & $\mathrm{Au}$ NPs & $6-60 \mathrm{~nm}$ & $\begin{array}{l}\text { Au NPs show good antimicrobial } \\
\text { activity against } S \text {. aureus compared } \\
\text { to } E \text {. coli. }\end{array}$ & [159] \\
\hline $\begin{array}{l}\text { P. aeruginosa PPAO1, } \\
\text { Serratia marcescens }\end{array}$ & $\mathrm{Au}$ NPs & $19.97 \mathrm{~nm}$ & $\begin{array}{l}\text { Au NPs can inhibit the biofilm } \\
\text { formation and EPS creation of } \\
\text { both bacteria. }\end{array}$ & [160] \\
\hline St. aureus & $\mathrm{Au}$ NPs & $\begin{array}{l}12 \mathrm{~nm} \\
\text { (aptamer-Au } \\
\text { NPs) }\end{array}$ & $\begin{array}{l}\text { Detection of } S . \text { aureus by } \\
\text { Van-modified Au NCs and } \\
\text { aptamer-modified Au NPs in } \\
30 \text { min with LOD was } \\
10 \text { CFU mL } \mathrm{mL}^{-1} \text {. }\end{array}$ & [161] \\
\hline P.aeruginosa, E. coli & $\mathrm{Au}$ NPs & NA & $\begin{array}{l}\text { Inhibition of efflux pump by } \\
\text { Emb-chi- Au NPs. }\end{array}$ & [162] \\
\hline P. acnes, S. aureus & Au nanorods & $\begin{array}{l}\text { Length and width } \\
\text { of } \sim 49 \mathrm{~nm} \text { and } \\
\quad \sim 12 \mathrm{~nm}\end{array}$ & $\begin{array}{l}\text { Au nanorods showed a greater } \\
\text { MIC than unpurified ones, which } \\
\text { shows that impurities have a chief } \\
\text { effect on the antibacterial activity. }\end{array}$ & [163] \\
\hline E. coli, S. aureus & $\begin{array}{l}\text { Au nanostars modified } \\
\text { with various thiol } \\
\text { groups }\end{array}$ & $\begin{array}{c}\text { Central core } \\
\text { diameter of about } \\
18 \mathrm{~nm} \text {, branches } \\
\text { with a length of } \\
12 \mathrm{~nm}\end{array}$ & $\begin{array}{l}\text { About } 99 \% \text { of the bacterial strains } \\
\text { were removed after the } \\
\text { photothermal effect. }\end{array}$ & [164] \\
\hline $\begin{array}{l}\text { S. aureus, E. coli, } \\
\text { P. aeruginosa }\end{array}$ & $\begin{array}{c}\text { Thiol } \\
\text { chitosan-wrapped Au } \\
\text { nanoshells (TC-AuNSs) }\end{array}$ & $\sim 185 \mathrm{~nm}$ & $\begin{array}{l}\text { TC-AuNSs were capable of } \\
\text { destroying bacteria inside a short } \\
\text { time of NIR laser irradiation. }\end{array}$ & [165] \\
\hline E. coli, S. aureus & $\mathrm{Au}$ NPs & $\sim 2 \mathrm{~nm}$ & $\begin{array}{l}\text { More than a 3-log reduction in } \\
\text { viable } S \text {. aureus after } 6 \mathrm{~h} \text { of light } \\
\text { exposure. }\end{array}$ & [166] \\
\hline $\begin{array}{l}\text { E. coli, K. pneumoniae } \\
\text { and Enterobacter cloacae }\end{array}$ & $\begin{array}{l}\text { Dextran-capped Au } \\
\text { NPs }\end{array}$ & $\sim 23 \mathrm{~nm}$ & $\begin{array}{l}\text { MB@GNPDEX-ConA mediated } \\
\text { treatment against various } \\
\text { multi-drug resistant infections } \\
\text { with } 97 \% \text { killing of bacteria. }\end{array}$ & [158] \\
\hline
\end{tabular}

\begin{tabular}{|c|c|c|c|c|}
\hline $\begin{array}{l}\text { S. epidermidis, } S \text {. aureus, } \\
\text { B. subtilis } M D R \\
\text { S.epidermidis }\end{array}$ & $\begin{array}{c}\text { Aminosacharrides } \\
\text { D-glucosamine (GluN), } \\
\text { D-mannosamine } \\
\text { (ManN), } \\
\text { D-galactosamine } \\
\text { (GalN) Au NPs }\end{array}$ & $\sim 4 \mathrm{~nm}$ & $\begin{array}{l}\text { AuGluN exhibited the greatest } \\
\text { antibacterial activity with MIC of } \\
\text { less than } 4 \mu \mathrm{g} / \mathrm{mL} \text {. }\end{array}$ & [167] \\
\hline
\end{tabular}

St.aureus, E. coli

$\mathrm{Au}$ NPs

$2-5 \mathrm{~nm}$
PU- Au NPs-CV shows

antibacterial surfaces were

attained by $1 \mathrm{mg} / \mathrm{mL}$ swell encapsulation concentrations of $2 \mathrm{~nm}$ Au NPs.
Delivering Colistin through $\mathrm{Au}$ NPs exhibited a reduction in the MIC against $E$. coli with about a 6-time reduction detected compared to antibiotics alone.

AuNSTs and AuNFs triggered a reduction in the growth rate of bacteria by $\sim 60 \%$ and $76 \%$.
E. coli Colistin -Au NPs $\quad 5 \mathrm{~nm}$
Gold nanostars

(AuNSTs), gold nanoflowers (AuNFs)
AuNSTs: $\sim 26 \mathrm{~nm}$,

AuNFs: $\sim 40 \mathrm{~nm}$ 


\section{Challenges of Ag and Au NPs as Antibacterial Nanomedicines}

The development of Ag and Au-based antimicrobial therapeutics is a complicated subject since the acknowledgment of various silver resistant strains in recent years [25,171]. $\mathrm{Ag}$ and $\mathrm{Au}$ NPs can be applied as antibacterial agents to afford or transport drugs in a directed manner and can solve critical complications, including multidrug resistance [25]. Multifunctional Ag and Au-based materials can be applied in combination therapy [172] Metal-NPs can use their antibacterial activity through various mechanisms, including the interaction with the bacterial cell wall, inhibition of biofilm creation, production of ROS, and stimulation of intracellular effects [171].

Although Ag NPs have high antibacterial activity, the cytotoxicity of silver ions released through Ag NPs and their accumulation in the body may limit their applications in nanomedicine [173]. The Ag NPs also show toxicity against hepatocytes and fibroblasts or bone-marrow cells [174]. Bondarenko et al. showed that MIC values in bacteria in $\mathrm{Ag}$ and ZnO NPs are 7 and $500 \mathrm{mg} / \mathrm{L}$, respectively [175]. Researchers developed porous $\mathrm{Ag}-\mathrm{Au}$ nanosheets with lower cytotoxicity that had antibacterial properties similar to S. aureus strains [176]. The surface and size of NPs affect their toxicity [177]. Because of their small size, NPs can be transported to the systemic circulation after inhalation, skin contact, or oral administration. When NPs are in the bloodstream, they come in contact with various components of the blood and may disrupt the normal function of platelets, causing bleeding or thrombosis. The biocompatibility of NPs with blood elements is a controversial issue [178]. Overcoming MDRs has evolved to improve antibiotics, and as a result, nanomedicine delivery systems can provide ways to develop antimicrobial nanomedicine. The use of biological methods, such as greener assays or the use of greener solvents, are also probable to be useful both in the field of environmental remediation and in other significant areas [179].

The biocompatibility and easy synthesis of Au NPs have made them suitable candidates for medical applications, but whether they can be affected by intracellular agents remains to be seen. In fact, the small size of Au NPs enhances their antibacterial effects; these NPs are easily modified and they have significant antibacterial applicability [46]. As a result, Au NPs can be modified to increase their antibacterial properties in antibacterial clinical use, however, more research is needed to investigate the toxicity in the living environment after long periods and high doses. Despite various benefits, Au NPs have significantly lower antibacterial activity than Ag NPs [180]. Long-term in vivo safety and experimental explanations are important in transporting advanced therapeutics into the clinical field and in regulating their development. The safety of Au NPs was also evaluated through the healthy performance of mice and the lack of toxicities in the spleen and liver. Researchers performed a comparison to investigate the biological distribution of PEGylated-AuNPs vs. AuNPs alone with diameters ranging from $20 \mathrm{~nm}$ to $50 \mathrm{~nm}$. They showed that at 2 days after injection, accumulation in the liver and spleen was significantly reduced by PEGylation [181]. Another field where we consider needed development is in the standardization of experiments to gain comparable studies. We hope in the future to have effective and safe nanogold-based therapeutics where gold's abilities are proven to eliminate the threatening superbugs in the world. The comparison between the advantages and limitations of both Ag and Au NPS and the challenges ahead are given in Table 3.

According to the literature, another of the challenges that can be mentioned in the use of metals, especially heavy metals, such as copper, arsenic, cadmium, and thallium, is their effect in inducing an increase of antibiotic-resistant bacteria (ARBs) in water sources or the environment, and changes in antibiotic resistance. In addition to heavy metals, the combination of heavy metals and other noble metals, such as Au and Ag, can cause combined pollution happenstances. Pre-treatment of surface water can be a significant source of ARBs and antibiotic resistance genes (ARGs) and therefore determinants of antibiotic resistance in drinking water systems. Studies have shown that the resistance of bacteria to heavy metals and antibiotics can increase simultaneously with the existence of heavy metals. As a result, the presence of heavy metals can change the antibiotic resistance of water sources and indi- 
rectly increase the threat to human health $[182,183]$. More considerations are proposed to be remunerated on the environmental and safety complications. However, biosorbents can be used in heavy metal removal. These biosorbents exhibit elegant prospects as low-cost investments to protect the environment from pollution. To advance a constant biosorption procedure, more studies are required in biosorbent properties, in terms of zeta potential, the morphology of surface, and particle size, as these are significant in biosorption tests [184].

Table 3. Advantages and limitations of antibacterial Ag and Au NPs.

\begin{tabular}{|c|c|}
\hline Advantages & Limitations \\
\hline Crosses tissue barriers & Toxicity \\
\hline Controlled drug release & Accumulation if intravenously injected \\
\hline Production of ROS & $\begin{array}{l}\text { High systemic acquaintance to administered } \\
\text { drugs }\end{array}$ \\
\hline Antibacterial effect & Need equipment for mass production \\
\hline \multicolumn{2}{|l|}{ Photothermal effect } \\
\hline \multicolumn{2}{|l|}{ Low immunosuppression } \\
\hline Easy synthesis & \\
\hline
\end{tabular}

ARGs have the possibility to be transmitted through varied environments. Increased antibiotics have triggered horizontal gene transfers (HGT) in widespread ARGs in the environment. In fact, HGT permits bacteria to exchange their antibiotic resistance genes between varied species. The application of ultraviolet (UV) technology, in combination with other oxidants, peroxymonosulfate, and photocatalysts to engage the high reactivity of created reactive species, can be used to enhance the degradation efficacy of ARGs and decrease the migration of ARGs during the inactivation of microbes $[185,186]$.

\section{Conclusions and Future Direction}

AMR is a major threat in social and hospital settings and leads to many deaths. Trying to discover novel drugs to stop the development of drug resistance, therefore, is not a technological approach to restraint and control. AMR is corroding our capacity to control infections with current antibiotics and there is a need to develop new methods to combat it. Innovation and the development of metal NPs such as Au and Ag, due to their special antimicrobial properties, can be used as new tools to address this public health threat. Metal nanoparticles, such as Ag, can kill bacteria and prevent the formation of biofilms.

Nanomedicine research provides easy access to innovative and nano symmetric methods that ultimately enable us to design and build intelligent drug delivery systems with low toxicity and high efficiency that can be realized from the unique benefits of nanomedicines; from toxicity reduction to high efficiency, successful trials, and significant market outlook. In addition, the development of controlled drug/antibiotic delivery systems based on nanostructures such as Au NPs can be a very attractive and effective way to overcome AMR. However, one of the most important issues is the discussion of toxicity effects that make their use in clinical applications difficult. In addition, the antimicrobial effect of NPs is dose-dependent and requires the use of high concentrations of NPs above the MIC to achieve robust treatment results, along with potential toxicity. As a result, there are limitations on the dose of nanomaterial agents that limit their work in vivo and clinical systems. In addition to the bacterial cell membrane, the amount of ROS produced by bacterial cells can also damage the host cell's membranes. In general, more studies are needed using in vitro and in vivo models to ensure that more NPs can be used. Another way to combat AMR is to identify the risks associated with antibiotic-resistant bacteria in the environment or contaminated soils. This means that integrated and accurate assays are needed to be able to simultaneously identify different analytes, including antibiotic and pathogenic microbes. Utilizing the optical properties of metal NPs, including Au NPs, in combination with other polymers and other nanomaterials can be a promising choice for 
the simultaneous detection of complex biological and chemical mixtures in soil, as well as the development of optical and electrochemical biosensors. Therefore, using biosensors can provide accurate and rapid diagnoses and minimize the risk of AMR emissions into the environment.

Author Contributions: All authors have contributed to the conceptualization, writing and revising of the review manuscript including revisions. All authors have read and agreed to the published version of the manuscript.

Funding: This review article received no external funding.

Institutional Review Board Statement: Not applicable.

Informed Consent Statement: Not applicable.

Data Availability Statement: The data presented in this study are available on request from the corresponding author.

Conflicts of Interest: The authors declare no conflict of interest.

\section{References}

1. Serwecińska, L. Antimicrobials and Antibiotic-Resistant Bacteria: A Risk to the Environment and to Public Health. Water 2020, 12, 3313. [CrossRef]

2. Farjadian, F.; Moghoofei, M.; Mirkiani, S.; Ghasemi, A.; Rabiee, N.; Hadifar, S.; Beyzavi, A.; Karimi, M.; Hamblin, M.R. Bacterial components as naturally inspired nano-carriers for drug/gene delivery and immunization: Set the bugs to work? Biotechnol. Adv. 2018, 36, 968-985. [CrossRef]

3. van Duin, D.; Paterson, D.L. Multidrug-Resistant Bacteria in the Community: Trends and Lessons Learned. Infect. Dis. Clin. N. Am. 2016, 30, 377-390. [CrossRef] [PubMed]

4. $\quad$ Darbasizadeh, B.; Fatahi, Y.; Feyzi-Barnaji, B.; Arabi, M.; Motasadizadeh, H.; Farhadnejad, H.; Moraffah, F.; Rabiee, N. Crosslinkedpolyvinyl alcohol-carboxymethyl cellulose/ZnO nanocomposite fibrous mats containing erythromycin (PVA-CMC/ZnO-EM): Fabrication, characterization and in-vitro release and anti-bacterial properties. Int. J. Biol. Macromol. 2019, 141, 1137-1146. [CrossRef] [PubMed]

5. Llor, C.; Bjerrum, L. Antimicrobial resistance: Risk associated with antibiotic overuse and initiatives to reduce the problem. Ther. Adv. Drug Saf. 2014, 5, 229-241. [CrossRef]

6. Donà, D.; Di Chiara, C.; Sharland, M. Multi-drug-resistant infections in the COVID-19 era: A framework for considering the potential impact. J. Hosp. Infect. 2020, 106, 198-199. [CrossRef]

7. Saunders-Hastings, P.R.; Krewski, D. Reviewing the History of Pandemic Influenza: Understanding Patterns of Emergence and Transmission. Pathogens 2016, 5, 66. [CrossRef]

8. Nasseri, B.; Soleimani, N.; Rabiee, N.; Kalbasi, A.; Karimi, M.; Hamblin, M.R. Point-of-care microfluidic devices for pathogen detection. Biosens. Bioelectron. 2018, 117, 112-128. [CrossRef]

9. Rabiee, N.; Bagherzadeh, M.; Ghasemi, A.; Zare, H.; Ahmadi, S.; Fatahi, Y.; Dinarvand, R.; Rabiee, M.; Ramakrishna, S.; Shokouhimehr, M. Point-of-use rapid detection of Sars-CoV-2: Nanotechnology-enabled solutions for the COVID-19 pandemic. Int. J. Mol. Sci. 2020, 21, 5126. [CrossRef]

10. Ahmadi, S.; Rabiee, N.; Fatahi, Y.; Hooshmand, S.E.; Bagherzadeh, M.; Rabiee, M.; Jajarmi, V.; Dinarvand, R.; Habibzadeh, S.; Saeb, M.R. Green chemistry and coronavirus. Sustain. Chem. Pharm. 2021, 21, 100415. [CrossRef]

11. Monowar, T.; Rahman, M.S.; Bhore, S.J.; Sathasivam, K.V. Endophytic Bacteria Enterobacter hormaechei Fabricated Silver Nanoparticles and Their Antimicrobial Activity. Pharmaceutics 2021, 13, 511. [CrossRef] [PubMed]

12. Hajebi, S.; Rabiee, N.; Bagherzadeh, M.; Ahmadi, S.; Rabiee, M.; Roghani-Mamaqani, H.; Tahriri, M.; Tayebi, L.; Hamblin, M.R. Stimulus-responsive polymeric nanogels as smart drug delivery systems. Acta Biomater. 2019, 92, 1-18. [CrossRef] [PubMed]

13. Nik, A.B.; Zare, H.; Razavi, S.; Mohammadi, H.; Ahmadi, P.T.; Yazdani, N.; Bayandori, M.; Rabiee, N.; Mobarakeh, J.I. Smart drug delivery: Capping strategies for mesoporous silica nanoparticles. Microporous Mesoporous Mater. 2020, $299,110115$.

14. Munita, J.M.; Arias, C.A. Mechanisms of Antibiotic Resistance. Microbiol. Spectr. 2016, 4, 34. [CrossRef]

15. Rabiee, N.; Ahmadi, S.; Fatahi, Y.; Rabiee, M.; Bagherzadeh, M.; Dinarvand, R.; Bagheri, B.; Zarrintaj, P.; Saeb, M.R.; Webster, T.J. Nanotechnology-assisted microfluidic systems: From bench to bedside. Nanomedicine 2020, 16, 237-258. [CrossRef]

16. Magiorakos, A.P.; Srinivasan, A.; Carey, R.B.; Carmeli, Y.; Falagas, M.E.; Giske, C.G.; Harbarth, S.; Hindler, J.F.; Kahlmeter, G.; Olsson-Liljequist, B.; et al. Multidrug-resistant, extensively drug-resistant and pandrug-resistant bacteria: An international expert proposal for interim standard definitions for acquired resistance. Clin. Microbiol. Infect. Off. Publ. Eur. Soc. Clin. Microbiol. Infect. Dis. 2012, 18, 268-281. [CrossRef]

17. Nour, S.; Baheiraei, N.; Imani, R.; Khodaei, M.; Alizadeh, A.; Rabiee, N.; Moazzeni, S.M. A review of accelerated wound healing approaches: Biomaterial-assisted tissue remodeling. J. Mater. Sci. Mater. Med. 2019, 30, 1-15. [CrossRef] 
18. Zare, H.; Ahmadi, S.; Ghasemi, A.; Ghanbari, M.; Rabiee, N.; Bagherzadeh, M.; Karimi, M.; Webster, T.J.; Hamblin, M.R.; Mostafavi, E. Carbon Nanotubes: Smart Drug/Gene Delivery Carriers. Int. J. Nanomed. 2021, 16, 1681. [CrossRef]

19. Rabiee, N.; Kiani, M.; Bagherzadeh, M.; Rabiee, M.; Ahmadi, S. Aptamer-based nanostructures. In Nanoparticle (NP)-Based Delivery Vehicles; Morgan \& Claypool Publishers: San Rafael, CA, USA, 2019.

20. Alkofide, H.; Alhammad, A.M.; Alruwaili, A.; Aldemerdash, A.; Almangour, T.A.; Alsuwayegh, A.; Almoqbel, D.; Albati, A.; Alsaud, A.; Enani, M. Multidrug-Resistant and Extensively Drug-Resistant Enterobacteriaceae: Prevalence, Treatments, and Outcomes-A Retrospective Cohort Study. Infect. Drug Resist. 2020, 13, 4653-4662. [CrossRef]

21. Saha, M.; Sarkar, A. Review on Multiple Facets of Drug Resistance: A Rising Challenge in the 21st Century. J. Xenobiotics 2021, 11, 197-214. [CrossRef]

22. Rabiee, N.; Bagherzadeh, M.; Tavakolizadeh, M.; Pourjavadi, A.; Atarod, M.; Webster, T.J. Synthesis, characterization and mechanistic study of nano chitosan tetrazole as a novel and promising platform for CRISPR delivery. Int. J. Polym. Mater. Polym. Biomater. 2020, 71, 116-126. [CrossRef]

23. Rabiee, N.; Bagherzadeh, M.; Heidarian Haris, M.; Ghadiri, A.M.; Matloubi Moghaddam, F.; Fatahi, Y.; Dinarvand, R.; Jarahiyan, A.; Ahmadi, S.; Shokouhimehr, M. Polymer-Coated NH2-UiO-66 for the Codelivery of DOX/pCRISPR. ACS Appl. Mater. Interfaces 2021, 13, 10796-10811. [CrossRef] [PubMed]

24. Lee, N.-Y.; Ko, W.-C.; Hsueh, P.-R. Nanoparticles in the Treatment of Infections Caused by Multidrug-Resistant Organisms. Front. Pharmacol. 2019, 10, 1153. [CrossRef]

25. Vatanpour, V.; Jouyandeh, M.; Khadem, S.S.M.; Paziresh, S.; Dehqan, A.; Ganjali, M.R.; Moradi, H.; Mirsadeghi, S.; Badiei, A.; Munir, M.T.; et al. Highly antifouling polymer-nanoparticle-nanoparticle/polymer hybrid membranes. Sci. Total Environ. 2022, 810, 152228. [CrossRef] [PubMed]

26. Ghasemi, A.; Rabiee, N.; Ahmadi, S.; Hashemzadeh, S.; Lolasi, F.; Bozorgomid, M.; Kalbasi, A.; Nasseri, B.; Dezfuli, A.S.; Aref, A.R. Optical assays based on colloidal inorganic nanoparticles. Analyst 2018, 143, 3249-3283. [CrossRef] [PubMed]

27. Rabiee, N.; Bagherzadeh, M.; Ghadiri, A.M.; Salehi, G.; Fatahi, Y.; Dinarvand, R. ZnAl nano layered double hydroxides for dual functional CRISPR/Cas9 delivery and enhanced green fluorescence protein biosensor. Sci. Rep. 2020, 10, 1-15. [CrossRef]

28. Maghsoudi, S.; Taghavi Shahraki, B.; Rabiee, N.; Fatahi, Y.; Bagherzadeh, M.; Dinarvand, R.; Ahmadi, S.; Rabiee, M.; Tahriri, M.; Hamblin, M.R. The colorful world of carotenoids: A profound insight on therapeutics and recent trends in nano delivery systems. Crit. Rev. Food Sci. Nutr. 2021, 61, 1-40. [CrossRef]

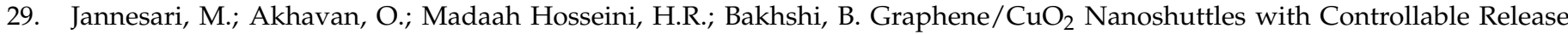
of Oxygen Nanobubbles Promoting Interruption of Bacterial Respiration. ACS Appl. Mater. Interfaces 2020, 12, 35813-35825. [CrossRef]

30. Ahmadi, S.; Rabiee, N.; Fatahi, Y.; Bagherzadeh, M.; Gachpazan, M.; Baheiraei, N.; Nasseri, B.; Karimi, M.; Webster, T.J.; Hamblin, M.R. Controlled gene delivery systems: Nanomaterials and chemical approaches. J. Biomed. Nanotechnol. 2020, 16, 553-582. [CrossRef]

31. Ghadiri, A.M.; Rabiee, N.; Bagherzadeh, M.; Kiani, M.; Fatahi, Y.; Di Bartolomeo, A.; Dinarvand, R.; Webster, T.J. Green synthesis of CuO-and Cu2O-NPs in assistance with high-gravity: The flowering of nanobiotechnology. Nanotechnology 2020, 31, 425101. [CrossRef]

32. Nayebi, B.; Rabiee, N.; Nayebi, B.; Asl, M.S.; Ramakrishna, S.; Jang, H.W.; Varma, R.S.; Shokouhimehr, M. Boron nitride-palladium nanostructured catalyst: Efficient reduction of nitrobenzene derivatives in water. Nano Express 2020, 1, 030012. [CrossRef]

33. Rabiee, N.; Ahmadi, S.; Afshari, R.; Khalaji, S.; Rabiee, M.; Bagherzadeh, M.; Fatahi, Y.; Dinarvand, R.; Tahriri, M.; Tayebi, L. Polymeric Nanoparticles for Nasal Drug Delivery to the Brain: Relevance to Alzheimer's Disease. Adv. Ther. 2021, 4, 2000076. [CrossRef]

34. Kiani, M.; Rabiee, N.; Bagherzadeh, M.; Ghadiri, A.M.; Fatahi, Y.; Dinarvand, R.; Webster, T.J. High-gravity-assisted green synthesis of palladium nanoparticles: The flowering of nanomedicine. Nanomed. Nanotechnol. Biol. Med. 2020, $30,102297$. [CrossRef] [PubMed]

35. Kiani, M.; Bagherzadeh, M.; Kaveh, R.; Rabiee, N.; Fatahi, Y.; Dinarvand, R.; Jang, H.W.; Shokouhimehr, M.; Varma, R.S. Novel $\mathrm{Pt}-\mathrm{Ag}_{3} \mathrm{PO}_{4} / \mathrm{CdS} /$ Chitosan Nanocomposite with Enhanced Photocatalytic and Biological Activities. Nanomaterials 2020, 10, 2320. [CrossRef] [PubMed]

36. Raza, M.A.; Kanwal, Z.; Rauf, A.; Sabri, A.N.; Riaz, S.; Naseem, S. Size- and Shape-Dependent Antibacterial Studies of Silver Nanoparticles Synthesized by Wet Chemical Routes. Nanomaterials 2016, 6, 74. [CrossRef]

37. Shahraki, B.T.; Maghsoudi, S.; Fatahi, Y.; Rabiee, N.; Bahadorikhalili, S.; Dinarvand, R.; Bagherzadeh, M.; Verpoort, F. The flowering of mechanically interlocked molecules: Novel approaches to the synthesis of rotaxanes and catenanes. Coord. Chem. Rev. 2020, 423, 213484. [CrossRef]

38. Toudeshkchoui, M.G.; Rabiee, N.; Rabiee, M.; Bagherzadeh, M.; Tahriri, M.; Tayebi, L.; Hamblin, M.R. Microfluidic devices with gold thin film channels for chemical and biomedical applications: A review. Biomed. Microdevices 2019, 21, 93. [CrossRef]

39. Kiani, M.; Rabiee, N.; Bagherzadeh, M.; Ghadiri, A.M.; Fatahi, Y.; Dinarvand, R.; Webster, T.J. Improved green biosynthesis of chitosan decorated Ag-and Co3O4-nanoparticles: A relationship between surface morphology, Photocatalytic and biomedical applications. Nanomed. Nanotechnol. Biol. Med. 2021, 32, 102331. [CrossRef]

40. Wolska, K.I.; Grześ, K.; Kurek, A. Synergy between novel antimicrobials and conventional antibiotics or bacteriocins. Pol. J. Microbiol. 2012, 61, 95-104. [CrossRef] 
41. Markowska, K.; Grudniak, A.M.; Wolska, K.I. Silver nanoparticles as an alternative strategy against bacterial biofilms. Acta Biochim. Pol. 2013, 60, 523-530. [CrossRef]

42. Rabiee, N.; Bagherzadeh, M.; Ghadiri, A.M.; Fatahi, Y.; Aldhaher, A.; Makvandi, P.; Dinarvand, R.; Jouyandeh, M.; Saeb, M.R.; Mozafari, M. Turning Toxic Nanomaterials into a Safe and Bioactive Nanocarrier for Co-delivery of DOX/pCRISPR. ACS Appl. Bio Mater. 2021, 4, 5336-5351. [CrossRef]

43. Arya, S.S.; Sharma, M.M.; Das, R.K.; Rookes, J.; Cahill, D.; Lenka, S.K. Vanillin mediated green synthesis and application of gold nanoparticles for reversal of antimicrobial resistance in Pseudomonas aeruginosa clinical isolates. Heliyon 2019, 5, e02021. [CrossRef] [PubMed]

44. Venditti, I. Engineered Gold-Based Nanomaterials: Morphologies and Functionalities in Biomedical Applications. A Mini Review. Bioengineering 2019, 6, 53. [CrossRef] [PubMed]

45. Lee, J.-H.; Cho, H.-Y.; Choi, H.K.; Lee, J.-Y.; Choi, J.-W. Application of Gold Nanoparticle to Plasmonic Biosensors. Int. J. Mol. Sci. 2018, 19, 2021. [CrossRef] [PubMed]

46. Okkeh, M.; Bloise, N.; Restivo, E.; De Vita, L.; Pallavicini, P.; Visai, L. Gold Nanoparticles: Can They Be the Next Magic Bullet for Multidrug-Resistant Bacteria? Nanomaterials 2021, 11, 312. [CrossRef]

47. Teixeira, M.C.; Carbone, C.; Sousa, M.C.; Espina, M.; Garcia, M.L.; Sanchez-Lopez, E.; Souto, E.B. Nanomedicines for the Delivery of Antimicrobial Peptides (AMPs). Nanomaterials 2020, 10, 560. [CrossRef]

48. Tao, C. Antimicrobial activity and toxicity of gold nanoparticles: Research progress, challenges and prospects. Lett. Appl. Microbiol. 2018, 67, 537-543. [CrossRef]

49. Nasr, S.M.; Rabiee, N.; Hajebi, S.; Ahmadi, S.; Fatahi, Y.; Hosseini, M.; Bagherzadeh, M.; Ghadiri, A.M.; Rabiee, M.; Jajarmi, V. Biodegradable nanopolymers in cardiac tissue engineering: From concept towards nanomedicine. Int. J. Nanomed. 2020, 15, 4205. [CrossRef]

50. Vafajoo, A.; Rostami, A.; Parsa, S.F.; Salarian, R.; Rabiee, N.; Rabiee, G.; Rabiee, M.; Tahriri, M.; Vashaee, D.; Tayebi, L. Multiplexed microarrays based on optically encoded microbeads. Biomed. Microdevices 2018, 20, 66. [CrossRef]

51. Burygin, G.L.; Khlebtsov, B.N.; Shantrokha, A.N.; Dykman, L.A.; Bogatyrev, V.A.; Khlebtsov, N.G. On the Enhanced Antibacterial Activity of Antibiotics Mixed with Gold Nanoparticles. Nanoscale Res. Lett. 2009, 4, 794-801. [CrossRef]

52. Ivanova, N.; Gugleva, V.; Dobreva, M.; Pehlivanov, I.; Stefanov, S.; Andonova, V. Silver Nanoparticles as Multi-Functional Drug Delivery Systems. In Nanomedicines; IntechOpen: London, UK, 2018.

53. Rabiee, N.; Khatami, M.; Jamalipour Soufi, G.; Fatahi, Y.; Iravani, S.; Varma, R.S. Diatoms with Invaluable Applications in Nanotechnology, Biotechnology, and Biomedicine: Recent Advances. ACS Biomater. Sci. Eng. 2021, 7, 3053-3068. [CrossRef]

54. Iravani, S.; Korbekandi, H.; Mirmohammadi, S.V.; Zolfaghari, B. Synthesis of silver nanoparticles: Chemical, physical and biological methods. Res. Pharm. Sci. 2014, 9, 385-406. [PubMed]

55. Kalishwaralal, K.; BarathManiKanth, S.; Pandian, S.R.; Deepak, V.; Gurunathan, S. Silver nanoparticles impede the biofilm formation by Pseudomonas aeruginosa and Staphylococcus epidermidis. Colloids Surfaces. B Biointerfaces 2010, 79, 340-344. [CrossRef] [PubMed]

56. Naseri, N.; Azimirad, R.; Akhavan, O.; Moshfegh, A. Improved electrochromical properties of sol-gel $\mathrm{WO}_{3}$ thin films by doping gold nanocrystals. Thin Solid Films 2010, 518, 2250-2257. [CrossRef]

57. Turkevich, J.; Stevenson, P.C.; Hillier, J. A study of the nucleation and growth processes in the synthesis of colloidal gold. Discuss. Faraday Soc. 1951, 11, 55-75. [CrossRef]

58. Ahmadi, S.; Kamaladini, H.; Haddadi, F.; Sharifmoghadam, M.R. Thiol-Capped Gold Nanoparticle Biosensors for Rapid and Sensitive Visual Colorimetric Detection of Klebsiella pneumoniae. J. Fluoresc. 2018, 28, 987-998. [CrossRef]

59. Frens, G. Controlled Nucleation for the Regulation of the Particle Size in Monodisperse Gold Suspensions. Nat. Phys. Sci. 1973, 241, 20-22. [CrossRef]

60. Yonezawa, T.; Kunitake, T. Practical preparation of anionic mercapto ligand-stabilized gold nanoparticles and their immobilization Colloids Surf. A Physicochem. Eng. Asp. 1999, 149, 193-199. [CrossRef]

61. Azzazy, H.M.; Mansour, M.M.; Samir, T.M.; Franco, R. Gold nanoparticles in the clinical laboratory: Principles of preparation and applications. Clin. Chem. Lab. Med. 2011, 50, 193-209. [CrossRef]

62. Sangpour, P.; Akhavan, O.; Moshfegh, A. The effect of Au/Ag ratios on surface composition and optical properties of co-sputtered alloy nanoparticles in $\mathrm{Au}-\mathrm{Ag}: \mathrm{SiO}_{2}$ thin films. J. Alloy. Compd. 2009, 486, 22-28. [CrossRef]

63. Brust, M.; Walker, M.; Bethell, D.; Schiffrin, D.J.; Whyman, R. Synthesis of thiol-derivatised gold nanoparticles in a two-phase Liquid-Liquid system. J. Chem. Soc. Chem. Commun. 1994, 7, 801-802. [CrossRef]

64. Babapour, A.; Akhavan, O.; Azimirad, R.; Moshfegh, A. Physical characteristics of heat-treated nano-silvers dispersed in sol-gel silica matrix. Nanotechnology 2006, 17, 763. [CrossRef]

65. Saeb, M.R.; Rabiee, N.; Seidi, F.; Far, B.F.; Bagherzadeh, M.; Lima, E.C.; Rabiee, M. Green CoNi ${ }_{2} \mathrm{~S}_{4} / \mathrm{Porphyrin}_{\mathrm{Decorated}}$ Carbon-based Nanocomposites for Genetic Materials Detection. J. Bioresour. Bioprod. 2021, 6, 215-222.

66. Lee, D.K.; Kang, Y.S. Synthesis of Silver Nanocrystallites by a New Thermal Decomposition Method and Their Characterization. ETRI J. 2004, 26, 252-256. [CrossRef]

67. Akhavan, O.; Azimirad, R.; Moshfegh, A. Low temperature self-agglomeration of metallic Ag nanoparticles on silica sol-gel thin films. J. Phys. D Appl. Phys. 2008, 41, 195305. [CrossRef]

68. Akhavan, O. Silver nanocube crystals on titanium nitride buffer layer. J. Phys. D Appl. Phys. 2009, 42, 105305. [CrossRef] 
69. Elsupikhe, R.F.; Ahmad, M.B.; Shameli, K.; Ibrahim, N.A.; Zainuddin, N. Photochemical Reduction as a Green Method for the Synthesis and Size Control of Silver Nanoparticles in k-Carrageenan. IEEE Trans. Nanotechnol. 2016, 15, 209-213. [CrossRef]

70. dos Santos, M.A.; Paterno, L.G.; Moreira, S.G.C.; Sales, M.J.A. Original photochemical synthesis of Ag nanoparticles mediated by potato starch. SN Appl. Sci. 2019, 1, 554. [CrossRef]

71. Mallick, K.; Wang, Z.L.; Pal, T. Seed-mediated successive growth of gold particles accomplished by UV irradiation: A photochemical approach for size-controlled synthesis. J. Photochem. Photobiol. A Chem. 2001, 140, 75-80. [CrossRef]

72. Jara, N.; Milán, N.S.; Rahman, A.; Mouheb, L.; Boffito, D.C.; Jeffryes, C.; Dahoumane, S.A. Photochemical Synthesis of Gold and Silver Nanoparticles-A Review. Molecules 2021, 26, 4585. [CrossRef]

73. Raveendran, P.; Fu, J.; Wallen, S.L. Completely "green" synthesis and stabilization of metal nanoparticles. J. Am. Chem. Soc. 2003, 125, 13940-13941. [CrossRef] [PubMed]

74. Mittelman, A.M.; Fortner, J.D.; Pennell, K.D. Effects of ultraviolet light on silver nanoparticle mobility and dissolution. Environ. Sci. Nano 2015, 2, 683-691. [CrossRef]

75. Link, S.; Burda, C.; Nikoobakht, B.; El-Sayed, M.A. Laser-Induced Shape Changes of Colloidal Gold Nanorods Using Femtosecond and Nanosecond Laser Pulses. J. Phys. Chem. B 2000, 104, 6152-6163. [CrossRef]

76. Mafuné, F.; Kohno, J.-y.; Takeda, Y.; Kondow, T.; Sawabe, H. Formation of Gold Nanoparticles by Laser Ablation in Aqueous Solution of Surfactant. J. Phys. Chem. B 2001, 105, 5114-5120. [CrossRef]

77. Mafuné, F.; Kohno, J.-y.; Takeda, Y.; Kondow, T.; Sawabe, H. Structure and Stability of Silver Nanoparticles in Aqueous Solution Produced by Laser Ablation. J. Phys. Chem. B 2000, 104, 8333-8337. [CrossRef]

78. Guo, W.; Pi, Y.; Song, H.; Tang, W.; Sun, J. Layer-by-layer assembled gold nanoparticles modified anode and its application in microbial fuel cells. Colloids Surf. A Physicochem. Eng. Asp. 2012, 415, 105-111. [CrossRef]

79. Hosseini, M.; Rabiee, N.; Bagherzadeh, M. Targeted delivery of nucleic acids using microfluidic systems. In Biomedical Applications of Microfluidic Devices; Elsevier: Amsterdam, The Netherlands, 2021; pp. 289-318.

80. Rezende, T.S.; Andrade, G.R.S.; Barreto, L.S.; Costa, N.B.; Gimenez, I.F.; Almeida, L.E. Facile preparation of catalytically active gold nanoparticles on a thiolated chitosan. Mater. Lett. 2010, 64, 882-884. [CrossRef]

81. Kharati, M.; Foroutanparsa, S.; Rabiee, M.; Salarian, R.; Rabiee, N.; Rabiee, G. Early diagnosis of multiple sclerosis based on optical and electrochemical biosensors: Comprehensive perspective. Curr. Anal. Chem. 2020, 16, 557-569. [CrossRef]

82. Kiani, M.; Bagherzadeh, M.; Meghdadi, S.; Rabiee, N.; Abbasi, A.; Schenk-Joß, K.; Tahriri, M.; Tayebi, L.; Webster, T.J. Development of a novel carboxamide-based off-on switch fluorescence sensor: $\mathrm{Hg}^{2+}, \mathrm{Zn}^{2+}$ and $\mathrm{Cd}^{2+}$. New J. Chem. 2020, 44, 11841-11852. [CrossRef]

83. Slepička, P.; Slepičková Kasálková, N.; Siegel, J.; Kolská, Z.; Švorčík, V. Methods of Gold and Silver Nanoparticles Preparation. Materials 2019, 13, 1. [CrossRef]

84. Garibo, D.; Borbón-Nuñez, H.A.; de León, J.N.D.; García Mendoza, E.; Estrada, I.; Toledano-Magaña, Y.; Tiznado, H.; OvalleMarroquin, M.; Soto-Ramos, A.G.; Blanco, A.; et al. Green synthesis of silver nanoparticles using Lysiloma acapulcensis exhibit high-antimicrobial activity. Sci. Rep. 2020, 10, 12805. [CrossRef] [PubMed]

85. Singh, A.; Gautam, P.K.; Verma, A.; Singh, V.; Shivapriya, P.M.; Shivalkar, S.; Sahoo, A.K.; Samanta, S.K. Green synthesis of metallic nanoparticles as effective alternatives to treat antibiotics resistant bacterial infections: A review. Biotechnol. Rep. 2020, 25, e00427. [CrossRef] [PubMed]

86. Rónavári, A.; Igaz, N.; Adamecz, D.I.; Szerencsés, B.; Molnar, C.; Kónya, Z.; Pfeiffer, I.; Kiricsi, M. Green Silver and Gold Nanoparticles: Biological Synthesis Approaches and Potentials for Biomedical Applications. Molecules 2021, 26, 844. [CrossRef]

87. Rabiee, N.; Bagherzadeh, M.; Kiani, M.; Ghadiri, A.M.; Zhang, K.; Jin, Z.; Ramakrishna, S.; Shokouhimehr, M. High gravityassisted green synthesis of $\mathrm{ZnO}$ nanoparticles via Allium ursinum: Conjoining nanochemistry to neuroscience. Nano Express 2020, 1, 020025. [CrossRef]

88. Javaid, A.; Oloketuyi, S.F.; Khan, M.M.; Khan, F. Diversity of Bacterial Synthesis of Silver Nanoparticles. BioNanoScience 2018, 8, 43-59. [CrossRef]

89. Rónavári, A.; Igaz, N.; Gopisetty, M.K.; Szerencsés, B.; Kovács, D.; Papp, C.; Vágvölgyi, C.; Boros, I.M.; Kónya, Z.; Kiricsi, M.; et al. Biosynthesized silver and gold nanoparticles are potent antimycotics against opportunistic pathogenic yeasts and dermatophytes. Int. J. Nanomed. 2018, 13, 695-703. [CrossRef]

90. Qing, Y.a.; Cheng, L.; Li, R.; Liu, G.; Zhang, Y.; Tang, X.; Wang, J.; Liu, H.; Qin, Y. Potential antibacterial mechanism of silver nanoparticles and the optimization of orthopedic implants by advanced modification technologies. Int. J. Nanomed. 2018, 13, 3311-3327. [CrossRef]

91. Zawadzka, K.; Felczak, A.; Nowak, M.; Kowalczyk, A.; Piwoński, I.; Lisowska, K. Antimicrobial activity and toxicological risk assessment of silver nanoparticles synthesized using an eco-friendly method with Gloeophyllum striatum. J. Hazard. Mater. 2021, 418, 126316. [CrossRef]

92. Akhavan, O.; Ghaderi, E. Bactericidal effects of Ag nanoparticles immobilized on surface of $\mathrm{SiO}_{2}$ thin film with high concentration. Curr. Appl. Phys. 2009, 9, 1381-1385. [CrossRef]

93. Kukushkina, E.A.; Hossain, S.I.; Sportelli, M.C.; Ditaranto, N.; Picca, R.A.; Cioffi, N. Ag-Based Synergistic Antimicrobial Composites. A Critical Review. Nanomaterials 2021, 11, 1687. [CrossRef]

94. Patil, M.P.; Kim, G.-D. Eco-friendly approach for nanoparticles synthesis and mechanism behind antibacterial activity of silver and anticancer activity of gold nanoparticles. Appl. Microbiol. Biotechnol. 2017, 101, 79-92. [CrossRef] [PubMed] 
95. van Hoek, A.H.A.M.; Mevius, D.; Guerra, B.; Mullany, P.; Roberts, A.P.; Aarts, H.J.M. Acquired antibiotic resistance genes: An overview. Front. Microbiol. 2011, 2, 203. [CrossRef] [PubMed]

96. Abdi, S.N.; Ghotaslou, R.; Ganbarov, K.; Mobed, A.; Tanomand, A.; Yousefi, M.; Asgharzadeh, M.; Kafil, H.S. Acinetobacter baumannii Efflux Pumps and Antibiotic Resistance. Infect. Drug Resist. 2020, 13, 423. [CrossRef]

97. Lara, H.H.; Ayala-Núñez, N.V.; Ixtepan Turrent, L.d.C.; Rodríguez Padilla, C. Bactericidal effect of silver nanoparticles against multidrug-resistant bacteria. World J. Microbiol. Biotechnol. 2010, 26, 615-621. [CrossRef]

98. Liao, S.; Zhang, Y.; Pan, X.; Zhu, F.; Jiang, C.; Liu, Q.; Cheng, Z.; Dai, G.; Wu, G.; Wang, L.; et al. Antibacterial activity and mechanism of silver nanoparticles against multidrug-resistant Pseudomonas aeruginosa. Int. J. Nanomed. 2019, 14, 1469-1487. [CrossRef] [PubMed]

99. Mickymaray, S. One-step Synthesis of Silver Nanoparticles Using Saudi Arabian Desert Seasonal Plant Sisymbrium irio and Antibacterial Activity Against Multidrug-Resistant Bacterial Strains. Biomolecules 2019, 9, 662. [CrossRef]

100. Illanes Tormena, R.P.; Rosa, E.V.; Oliveira Mota, B.d.F.; Chaker, J.A.; Fagg, C.W.; Freire, D.O.; Martins, P.M.; Rodrigues da Silva, I.C.; Sousa, M.H. Evaluation of the antimicrobial activity of silver nanoparticles obtained by microwave-assisted green synthesis using Handroanthus impetiginosus (Mart. ex DC.) Mattos underbark extract. RSC Adv. 2020, 10, 20676-20681. [CrossRef]

101. Singh, P.; Pandit, S.; Jers, C.; Joshi, A.S.; Garnæs, J.; Mijakovic, I. Silver nanoparticles produced from Cedecea sp. exhibit antibiofilm activity and remarkable stability. Sci. Rep. 2021, 11, 12619. [CrossRef]

102. Du, L.; Li, T.; Wu, S.; Zhu, H.F.; Zou, F.Y. Electrospun composite nanofibre fabrics containing green reduced Ag nanoparticles as an innovative type of antimicrobial insole. RSC Adv. 2019, 9, 2244-2251. [CrossRef]

103. Akhavan, O.; Abdolahad, M.; Abdi, Y.; Mohajerzadeh, S. Silver nanoparticles within vertically aligned multi-wall carbon nanotubes with open tips for antibacterial purposes. J. Mater. Chem. 2011, 21, 387-393. [CrossRef]

104. Akhavan, $\mathrm{O}$. Lasting antibacterial activities of $\mathrm{Ag}-\mathrm{TiO}_{2} / \mathrm{Ag} / \mathrm{a}-\mathrm{TiO}_{2}$ nanocomposite thin film photocatalysts under solar light irradiation. J. Colloid Interface Sci. 2009, 336, 117-124. [CrossRef] [PubMed]

105. Akhavan, O.; Ghaderi, E. Self-accumulated Ag nanoparticles on mesoporous $\mathrm{TiO}_{2}$ thin film with high bactericidal activities. Surf. Coat. Technol. 2010, 204, 3676-3683. [CrossRef]

106. Liu, S.; Cao, S.; Guo, J.; Luo, L.; Zhou, Y.; Lin, C.; Shi, J.; Fan, C.; Lv, M.; Wang, L. Graphene oxide-silver nanocomposites modulate biofilm formation and extracellular polymeric substance (EPS) production. Nanoscale 2018, 10, 19603-19611. [CrossRef] [PubMed]

107. Akhavan, O.; Ghaderi, E. Enhancement of antibacterial properties of Ag nanorods by electric field. Sci. Technol. Adv. Mater. 2009, 10, 015003. [CrossRef] [PubMed]

108. Goel, N.; Ahmad, R.; Singh, R.; Sood, S.; Khare, S.K. Biologically synthesized silver nanoparticles by Streptomyces sp. EMB24 extracts used against the drug-resistant bacteria. Bioresour. Technol. Rep. 2021, 15, 100753. [CrossRef]

109. Guo, J.; Qin, S.; Wei, Y.; Liu, S.; Peng, H.; Li, Q.; Luo, L.; Lv, M. Silver nanoparticles exert concentration-dependent influences on biofilm development and architecture. Cell Prolif. 2019, 52, e12616. [CrossRef]

110. Ansari, M.A.; Kalam, A.; Al-Sehemi, A.G.; Alomary, M.N.; AlYahya, S.; Aziz, M.K.; Srivastava, S.; Alghamdi, S.; Akhtar, S.; Almalki, H.D.; et al. Counteraction of Biofilm Formation and Antimicrobial Potential of Terminalia catappa Functionalized Silver Nanoparticles against Candida albicans and Multidrug-Resistant Gram-Negative and Gram-Positive Bacteria. Antibiotics 2021, 10, 725. [CrossRef]

111. Regiel-Futyra, A.; Kus-Liśkiewicz, M.; Sebastian, V.; Irusta, S.; Arruebo, M.; Kyzioł, A.; Stochel, G. Development of noncytotoxic silver-chitosan nanocomposites for efficient control of biofilm forming microbes. RSC Adv. 2017, 7, 52398-52413. [CrossRef]

112. Akhavan, O.; Abdolahad, M.; Asadi, R. Storage of Ag nanoparticles in pore-arrays of SU-8 matrix for antibacterial applications. J Phys. D Appl. Phys. 2009, 42, 135416. [CrossRef]

113. Rezazadeh, N.H.; Buazar, F.; Matroodi, S. Synergistic effects of combinatorial chitosan and polyphenol biomolecules on enhanced antibacterial activity of biofunctionalized silver nanoparticles. Sci. Rep. 2020, 10, 19615. [CrossRef]

114. Katva, S.; Das, S.; Moti, H.S.; Jyoti, A.; Kaushik, S. Antibacterial Synergy of Silver Nanoparticles with Gentamicin and Chloramphenicol against Enterococcus faecalis. Pharmacogn. Mag. 2018, 13, S828-S833.

115. McShan, D.; Zhang, Y.; Deng, H.; Ray, P.C.; Yu, H. Synergistic Antibacterial Effect of Silver Nanoparticles Combined with Ineffective Antibiotics on Drug Resistant Salmonella typhimurium DT104. J. Environ. Sci. Health Part C Environ. Carcinog. Ecotoxicol. Rev. 2015, 33, 369-384. [CrossRef] [PubMed]

116. Li, Y.; Leung, P.; Yao, L.; Song, Q.W.; Newton, E. Antimicrobial effect of surgical masks coated with nanoparticles. J. Hosp. Infect. 2006, 62, 58-63. [CrossRef] [PubMed]

117. Sathishkumar, M.; Sneha, K.; Won, S.W.; Cho, C.W.; Kim, S.; Yun, Y.S. Cinnamon zeylanicum bark extract and powder mediated green synthesis of nano-crystalline silver particles and its bactericidal activity. Colloids Surf. B Biointerfaces 2009, 73, 332-338. [CrossRef] [PubMed]

118. Krishnaraj, C.; Jagan, E.G.; Rajasekar, S.; Selvakumar, P.; Kalaichelvan, P.T.; Mohan, N. Synthesis of silver nanoparticles using Acalypha indica leaf extracts and its antibacterial activity against water borne pathogens. Colloids Surf. B Biointerfaces 2010, 76, 50-56. [CrossRef]

119. Garza-Cervantes, J.A.; Mendiola-Garza, G.; de Melo, E.M.; Dugmore, T.I.J.; Matharu, A.S.; Morones-Ramirez, J.R. Antimicrobial activity of a silver-microfibrillated cellulose biocomposite against susceptible and resistant bacteria. Sci. Rep. 2020, $10,7281$. [CrossRef] 
120. Pareek, V.; Devineau, S.; Sivasankaran, S.K.; Bhargava, A.; Panwar, J.; Srikumar, S.; Fanning, S. Silver Nanoparticles Induce a Triclosan-Like Antibacterial Action Mechanism in Multi-Drug Resistant Klebsiella pneumoniae. Front. Microbiol. 2021, 12, 183. [CrossRef]

121. Qais, F.A.; Ahmad, I.; Altaf, M.; Manoharadas, S.; Al-Rayes, B.F.; Ali Abuhasil, M.S.; Almaroai, Y.A. Biofabricated silver nanoparticles exhibit broad-spectrum antibiofilm and antiquorum sensing activity against Gram-negative bacteria. RSC Adv. 2021, 11, 13700-13710. [CrossRef]

122. Gouyau, J.; Duval, R.E.; Boudier, A.; Lamouroux, E. Investigation of Nanoparticle Metallic Core Antibacterial Activity: Gold and Silver Nanoparticles against Escherichia coli and Staphylococcus aureus. Int. J. Mol. Sci. 2021, 22, 1905. [CrossRef]

123. Sadeghi, B.; Rostami, A.; Momeni, S.S. Facile green synthesis of silver nanoparticles using seed aqueous extract of Pistacia atlantica and its antibacterial activity. Spectrochim. Acta Part A Mol. Biomol. Spectrosc. 2015, 134, 326-332. [CrossRef]

124. Esmaeillou, M.; Zarrini, G.; Ahangarzadeh Rezaee, M.; Shahbazi Mojarrad, J.; Bahadori, A. Vancomycin Capped with Silver Nanoparticles as an Antibacterial Agent against Multi-Drug Resistance Bacteria. Adv. Pharm. Bull. 2017, 7, 479-483. [CrossRef] [PubMed]

125. Thapa, R.; Bhagat, C.; Shrestha, P.; Awal, S.; Dudhagara, P. Enzyme-mediated formulation of stable elliptical silver nanoparticles tested against clinical pathogens and MDR bacteria and development of antimicrobial surgical thread. Ann. Clin. Microbiol. Antimicrob. 2017, 16, 39. [CrossRef]

126. Ding, F.; Songkiatisak, P.; Cherukuri, P.K.; Huang, T.; Xu, X.-H.N. Size-Dependent Inhibitory Effects of Antibiotic Drug Nanocarriers against Pseudomonas aeruginosa. ACS Omega 2018, 3, 1231-1243. [CrossRef] [PubMed]

127. Chang, T.Y.; Chen, C.C.; Cheng, K.M.; Chin, C.Y.; Chen, Y.H.; Chen, X.A.; Sun, J.R.; Young, J.J.; Chiueh, T.S. Trimethyl chitosan-capped silver nanoparticles with positive surface charge: Their catalytic activity and antibacterial spectrum including multidrug-resistant strains of Acinetobacter baumannii. Colloids Surf. B Biointerfaces 2017, 155, 61-70. [CrossRef] [PubMed]

128. Han, C.; Romero, N.; Fischer, S.; Dookran, J.; Berger, A.; Doiron, A.L. Recent developments in the use of nanoparticles for treatment of biofilms. Nanotechnol. Rev. 2017, 6, 383-404. [CrossRef]

129. Taylor, E.N.; Kummer, K.M.; Durmus, N.G.; Leuba, K.; Tarquinio, K.M.; Webster, T.J. Superparamagnetic iron oxide nanoparticles (SPION) for the treatment of antibiotic-resistant biofilms. Small 2012, 8, 3016-3027. [CrossRef]

130. Singh, P.; Pandit, S.; Mokkapati, V.R.S.S.; Garg, A.; Ravikumar, V.; Mijakovic, I. Gold Nanoparticles in Diagnostics and Therapeutics for Human Cancer. Int. J. Mol. Sci. 2018, 19, 1979. [CrossRef]

131. Srinivas Raghavan, B.; Kondath, S.; Anantanarayanan, R.; Rajaram, R. Kaempferol mediated synthesis of gold nanoparticles and their cytotoxic effects on MCF-7 cancer cell line. Process Biochem. 2015, 50, 1966-1976. [CrossRef]

132. Kannan, R.; Rahing, V.; Cutler, C.; Pandrapragada, R.; Katti, K.K.; Kattumuri, V.; Robertson, J.D.; Casteel, S.J.; Jurisson, S.; Smith, C.; et al. Nanocompatible chemistry toward fabrication of target-specific gold nanoparticles. J. Am. Chem. Soc. 2006, 128, 11342-11343. [CrossRef]

133. Rajchakit, U.; Sarojini, V. Recent Developments in Antimicrobial-Peptide-Conjugated Gold Nanoparticles. Bioconjugate Chem. 2017, 28, 2673-2686. [CrossRef]

134. Aghamiri, S.; Rabiee, N.; Ahmadi, S.; Rabiee, M.; Bagherzadeh, M.; Karimi, M. Microfluidic devices: Synthetic approaches. In Biomedical Applications of Microfluidic Devices; Elsevier: Amsterdam, The Netherlands, 2021; pp. 23-36.

135. Jouyandeh, M.; Khadem, S.S.M.; Habibzadeh, S.; Esmaeili, A.; Abida, O.; Vatanpour, V.; Rabiee, N.; Bagherzadeh, M.; Iravani, S.; Saeb, M.R. Quantum dots for photocatalysis: Synthesis and environmental applications. Green Chem. 2021, 23, 4931-4954. [CrossRef]

136. Gu, H.; Ho, P.L.; Tong, E.; Wang, L.; Xu, B. Presenting Vancomycin on Nanoparticles to Enhance Antimicrobial Activities. Nano Lett. 2003, 3, 1261-1263. [CrossRef]

137. Casciaro, B.; Moros, M.; Rivera-Fernández, S.; Bellelli, A.; de la Fuente, J.M.; Mangoni, M.L. Gold-nanoparticles coated with the antimicrobial peptide esculentin-1a(1-21)NH2 as a reliable strategy for antipseudomonal drugs. Acta Biomater. 2017, 47, 170-181. [CrossRef] [PubMed]

138. Yeom, J.H.; Lee, B.; Kim, D.; Lee, J.K.; Kim, S.; Bae, J.; Park, Y.; Lee, K. Gold nanoparticle-DNA aptamer conjugate-assisted delivery of antimicrobial peptide effectively eliminates intracellular Salmonella enterica serovar Typhimurium. Biomaterials 2016, 104, 43-51. [CrossRef] [PubMed]

139. Peng, L.H.; Huang, Y.F.; Zhang, C.Z.; Niu, J.; Chen, Y.; Chu, Y.; Jiang, Z.H.; Gao, J.Q.; Mao, Z.W. Integration of antimicrobial peptides with gold nanoparticles as unique non-viral vectors for gene delivery to mesenchymal stem cells with antibacterial activity. Biomaterials 2016, 103, 137-149. [CrossRef]

140. Emmanuel, R.; Saravanan, M.; Ovais, M.; Padmavathy, S.; Shinwari, Z.K.; Prakash, P. Antimicrobial efficacy of drug blended biosynthesized colloidal gold nanoparticles from Justicia glauca against oral pathogens: A nanoantibiotic approach. Microb. Pathog. 2017, 113, 295-302. [CrossRef]

141. Aghamiri, S.; Rabiee, N.; Ahmadi, S.; Rabiee, M.; Bagherzadeh, M.; Karimi, M. Microfluidics: Organ-on-a-chip. In Biomedical Applications of Microfluidic Devices; Elsevier: Amsterdam, The Netherlands, 2021; pp. 99-115.

142. Maghsoudi, S.; Rabiee, N.; Ahmadi, S.; Rabiee, M.; Bagherzadeh, M.; Karimi, M. An overview of microfluidic devices. Biomed. Appl. Microfluid. Devices 2021,1-22. [CrossRef]

143. Weir, E.; Lawlor, A.; Whelan, A.; Regan, F. The use of nanoparticles in anti-microbial materials and their characterization. Analyst 2008, 133, 835-845. [CrossRef] 
144. Beyth, N.; Houri-Haddad, Y.; Domb, A.; Khan, W.; Hazan, R. Alternative Antimicrobial Approach: Nano-Antimicrobial Materials. Evid. -Based Complementary Altern. Med. 2015, 2015, 246012. [CrossRef]

145. Marcelo, G.A.; Duarte, M.P.; Oliveira, E. Gold@mesoporous silica nanocarriers for the effective delivery of antibiotics and by-passing of $\beta$-lactam resistance. SN Appl. Sci. 2020, 2, 1354. [CrossRef]

146. Nag, P.; Sadani, K.; Mukherji, S.; Mukherji, S. Beta-lactam antibiotics induced bacteriolysis on LSPR sensors for assessment of antimicrobial resistance and quantification of antibiotics. Sens. Actuators B Chem. 2020, 311, 127945. [CrossRef]

147. Samsuri, N.; Mukhtar, W.M.; Abd Rashid, A.R.; Dasuki, K.; Yussuf, A. Synthesis methods of gold nanoparticles for Localized Surface Plasmon Resonance (LSPR) sensor applications. EPJ Web Conf. 2017, 162, 01002. [CrossRef]

148. Shareena Dasari, T.P.; Zhang, Y.; Yu, H. Antibacterial Activity and Cytotoxicity of Gold (I) and (III) Ions and Gold Nanoparticles. Biochem. Pharmacol. Open Access 2015, 4, 199.

149. Torres, M.R.; Slate, A.J.; Ryder, S.F.; Akram, M.; Iruzubieta, C.J.C.; Whitehead, K.A. Ionic gold demonstrates antimicrobial activity against Pseudomonas aeruginosa strains due to cellular ultrastructure damage. Arch. Microbiol. 2021, 203, 3015-3024. [CrossRef] [PubMed]

150. Mahmoud, N.N.; Alhusban, A.A.; Ali, J.I.; Al-Bakri, A.G.; Hamed, R.; Khalil, E.A. Preferential Accumulation of Phospholipid-PEG and Cholesterol-PEG Decorated Gold Nanorods into Human Skin Layers and Their Photothermal-Based Antibacterial Activity. Sci. Rep. 2019, 9, 5796. [CrossRef]

151. Mahmoud, N.N.; Alkilany, A.M.; Khalil, E.A.; Al-Bakri, A.G. Nano-Photothermal ablation effect of Hydrophilic and Hydrophobic Functionalized Gold Nanorods on Staphylococcus aureus and Propionibacterium acnes. Sci. Rep. 2018, 8, 6881. [CrossRef]

152. Bankier, C.; Matharu, R.K.; Cheong, Y.K.; Ren, G.G.; Cloutman-Green, E.; Ciric, L. Synergistic Antibacterial Effects of Metallic Nanoparticle Combinations. Sci. Rep. 2019, 9, 16074. [CrossRef] [PubMed]

153. Ivanova, E.P.; Hasan, J.; Webb, H.K.; Truong, V.K.; Watson, G.S.; Watson, J.A.; Baulin, V.A.; Pogodin, S.; Wang, J.Y.; Tobin, M.J.; et al. Natural Bactericidal Surfaces: Mechanical Rupture of Pseudomonas aeruginosa Cells by Cicada Wings. Small 2012, 8, $2489-2494$. [CrossRef]

154. Al-Bakri, A.G.; Mahmoud, N.N. Photothermal-Induced Antibacterial Activity of Gold Nanorods Loaded into Polymeric Hydrogel against Pseudomonas aeruginosa Biofilm. Molecules 2019, 24, 2661. [CrossRef] [PubMed]

155. Bermúdez-Jiménez, C.; Romney, M.G.; Roa-Flores, S.A.; Martínez-Castañón, G.; Bach, H. Hydrogel-embedded gold nanorods activated by plasmonic photothermy with potent antimicrobial activity. Nanomed. Nanotechnol. Biol. Med. 2019, $22,102093$. [CrossRef] [PubMed]

156. Wang, C.; Wang, Y.; Zhang, L.; Miron, R.J.; Liang, J.; Shi, M.; Mo, W.; Zheng, S.; Zhao, Y.; Zhang, Y. Pretreated MacrophageMembrane-Coated Gold Nanocages for Precise Drug Delivery for Treatment of Bacterial Infections. Adv. Mater. 2018, 30, 1804023. [CrossRef] [PubMed]

157. Wu, S.; Li, A.; Zhao, X.; Zhang, C.; Yu, B.; Zhao, N.; Xu, F.-J. Silica-Coated Gold-Silver Nanocages as Photothermal Antibacterial Agents for Combined Anti-Infective Therapy. ACS Appl. Mater. Interfaces 2019, 11, 17177-17183. [CrossRef]

158. Khan, S.; Khan, S.N.; Meena, R.; Dar, A.M.; Pal, R.; Khan, A.U. Photoinactivation of multidrug resistant bacteria by monomeric methylene blue conjugated gold nanoparticles. J. Photochem. Photobiol. B Biol. 2017, 174, 150-161. [CrossRef]

159. Kumar, K.M.; Mandal, B.K.; Sinha, M.; Krishnakumar, V. Terminalia chebula mediated green and rapid synthesis of gold nanoparticles. Spectrochim. Acta Part A Mol. Biomol. Spectrosc. 2012, 86, 490-494. [CrossRef] [PubMed]

160. Qais, F.A.; Ahmad, I.; Altaf, M.; Alotaibi, S.H. Biofabrication of Gold Nanoparticles Using Capsicum annuum Extract and Its Antiquorum Sensing and Antibiofilm Activity against Bacterial Pathogens. ACS Omega 2021, 6, 16670-16682. [CrossRef]

161. Yu, M.; Wang, H.; Fu, F.; Li, L.; Li, J.; Li, G.; Song, Y.; Swihart, M.T.; Song, E. Dual-Recognition Förster Resonance Energy Transfer Based Platform for One-Step Sensitive Detection of Pathogenic Bacteria Using Fluorescent Vancomycin-Gold Nanoclusters and Aptamer-Gold Nanoparticles. Anal. Chem. 2017, 89, 4085-4090. [CrossRef]

162. Khare, T.; Mahalunkar, S.; Shriram, V.; Gosavi, S.; Kumar, V. Embelin-loaded chitosan gold nanoparticles interact synergistically with ciprofloxacin by inhibiting efflux pumps in multidrug-resistant Pseudomonas aeruginosa and Escherichia coli. Environ. Res. 2021, 199, 111321. [CrossRef] [PubMed]

163. Mahmoud, N.N.; Alkilany, A.M.; Khalil, E.A.; Al-Bakri, A.G. Antibacterial activity of gold nanorods against Staphylococcus aureus and Propionibacterium acnes: Misinterpretations and artifacts. Int. J. Nanomed. 2017, 12, 7311-7322. [CrossRef] [PubMed]

164. Rovati, D.; Albini, B.; Galinetto, P.; Grisoli, P.; Bassi, B.; Pallavicini, P.; Dacarro, G.; Taglietti, A. High Stability Thiol-Coated Gold Nanostars Monolayers with Photo-Thermal Antibacterial Activity and Wettability Control. Nanomaterials 2019, 9, 1288. [CrossRef]

165. Manivasagan, P.; Khan, F.; Hoang, G.; Mondal, S.; Kim, H.; Hoang Minh Doan, V.; Kim, Y.-M.; Oh, J. Thiol chitosan-wrapped gold nanoshells for near-infrared laser-induced photothermal destruction of antibiotic-resistant bacteria. Carbohydr. Polym. 2019, 225, 115228. [CrossRef]

166. Hwang, G.B.; Huang, H.; Wu, G.; Shin, J.; Kafizas, A.; Karu, K.; Toit, H.D.; Alotaibi, A.M.; Mohammad-Hadi, L.; Allan, E.; et al. Photobactericidal activity activated by thiolated gold nanoclusters at low flux levels of white light. Nat. Commun. 2020, 11, 1207. [CrossRef]

167. Yang, X.; Zhang, L.; Jiang, X. Aminosaccharide-gold nanoparticle assemblies as narrow-spectrum antibiotics against methicillinresistant Staphylococcus aureus. Nano Res. 2018, 11, 6237-6243. [CrossRef] 
168. Macdonald, T.J.; Wu, K.; Sehmi, S.K.; Noimark, S.; Peveler, W.J.; du Toit, H.; Voelcker, N.H.; Allan, E.; MacRobert, A.J.; Gavriilidis, A.; et al. Thiol-Capped Gold Nanoparticles Swell-Encapsulated into Polyurethane as Powerful Antibacterial Surfaces Under Dark and Light Conditions. Sci. Rep. 2016, 6, 39272. [CrossRef] [PubMed]

169. Fuller, M.; Whiley, H.; Köper, I. Antibiotic delivery using gold nanoparticles. SN Appl. Sci. 2020, 2, 1022. [CrossRef]

170. Penders, J.; Stolzoff, M.; Hickey, D.J.; Andersson, M.; Webster, T.J. Shape-dependent antibacterial effects of non-cytotoxic gold nanoparticles. Int. J. Nanomed. 2017, 12, 2457-2468. [CrossRef] [PubMed]

171. Baptista, P.V.; McCusker, M.P.; Carvalho, A.; Ferreira, D.A.; Mohan, N.M.; Martins, M.; Fernandes, A.R. Nano-Strategies to Fight Multidrug Resistant Bacteria-“A Battle of the Titans". Front. Microbiol. 2018, 9, 1441. [CrossRef]

172. Dykman, L.A.; Khlebtsov, N.G. Gold nanoparticles in chemo-, immuno-, and combined therapy: Review [Invited]. Biomed. Opt. Express 2019, 10, 3152-3182. [CrossRef]

173. Ferdous, Z.; Nemmar, A. Health Impact of Silver Nanoparticles: A Review of the Biodistribution and Toxicity Following Various Routes of Exposure. Int. J. Mol. Sci. 2020, 21, 2375. [CrossRef]

174. Gaiser, B.K.; Hirn, S.; Kermanizadeh, A.; Kanase, N.; Fytianos, K.; Wenk, A.; Haberl, N.; Brunelli, A.; Kreyling, W.G.; Stone, V. Effects of silver nanoparticles on the liver and hepatocytes in vitro. Toxicol. Sci. Off. J. Soc. Toxicol. 2013, 131, 537-547. [CrossRef]

175. Bondarenko, O.; Juganson, K.; Ivask, A.; Kasemets, K.; Mortimer, M.; Kahru, A. Toxicity of Ag, CuO and ZnO nanoparticles to selected environmentally relevant test organisms and mammalian cells in vitro: A critical review. Arch. Toxicol. 2013, 87, 1181-1200. [CrossRef]

176. Zhu, J.; Liu, S.; Zhang, T.; Zhang, Y.; Zhang, X.; Liu, X.; Tie, Z.; Dou, Y.; Lu, Z.; Hu, Y. Porous gold layer coated silver nanoplates with efficient antimicrobial activity. Colloids Surf. B Biointerfaces 2020, 186, 110727. [CrossRef]

177. Chandran, P.; Riviere, J.E.; Monteiro-Riviere, N.A. Surface chemistry of gold nanoparticles determines the biocorona composition impacting cellular uptake, toxicity and gene expression profiles in human endothelial cells. Nanotoxicology 2017, 11, 507-519. [CrossRef]

178. Hante, N.K.; Medina, C.; Santos-Martinez, M.J. Effect on Platelet Function of Metal-Based Nanoparticles Developed for Medical Applications. Front. Cardiovasc. Med. 2019, 6, 139. [CrossRef]

179. Cardoso-Avila, P.E.; Patakfalvi, R.; Rodríguez-Pedroza, C.; Aparicio-Fernández, X.; Loza-Cornejo, S.; Villa-Cruz, V.; MartínezCano, E. One-pot green synthesis of gold and silver nanoparticles using Rosa canina L. extract. RSC Adv. 2021, 11, 14624-14631. [CrossRef]

180. Sánchez-López, E.; Gomes, D.; Esteruelas, G.; Bonilla, L.; Lopez-Machado, A.L.; Galindo, R.; Cano, A.; Espina, M.; Ettcheto, M.; Camins, A.; et al. Metal-Based Nanoparticles as Antimicrobial Agents: An Overview. Nanomaterials 2020, 10, 292. [CrossRef]

181. Takeuchi, I.; Onaka, H.; Makino, K. Biodistribution of colloidal gold nanoparticles after intravenous injection: Effects of PEGylation at the same particle size. Bio-Med. Mater. Eng. 2018, 29, 205-215. [CrossRef]

182. Bai, Y.; Ruan, X.; Xie, X.; Yan, Z. Antibiotic resistome profile based on metagenomics in raw surface drinking water source and the influence of environmental factor: A case study in Huaihe River Basin, China. Environ. Pollut. 2019, 248, 438-447. [CrossRef]

183. Zhang, M.; Wan, K.; Zeng, J.; Lin, W.; Ye, C.; Yu, X. Co-selection and stability of bacterial antibiotic resistance by arsenic pollution accidents in source water. Environ. Int. 2020, 135, 105351. [CrossRef]

184. Ayangbenro, A.S.; Babalola, O.O. A New Strategy for Heavy Metal Polluted Environments: A Review of Microbial Biosorbents Int. J. Environ. Res. Public Health 2017, 14, 94. [CrossRef]

185. Sharma, V.K.; Yu, X.; McDonald, T.J.; Jinadatha, C.; Dionysiou, D.D.; Feng, M. Elimination of antibiotic resistance genes and control of horizontal transfer risk by UV-based treatment of drinking water: A mini review. Front. Environ. Sci. Eng. 2019, 13, 37. [CrossRef]

186. Sun, D.; Jeannot, K.; Xiao, Y.; Knapp, C.W. Editorial: Horizontal Gene Transfer Mediated Bacterial Antibiotic Resistance. Front. Microbiol. 2019, 10, 1933. [CrossRef] [PubMed] 